\title{
P2Y receptors in GtoPdb v.2021.3
}

Maria-Pia Abbracchio ${ }^{1}$, Jean-Marie Boeynaems ${ }^{2}$, José L. Boyer ${ }^{3}$, Geoffrey Burnstock ${ }^{4}$, Stefania Ceruti $^{1}$, Marta Fumagalli ${ }^{1}$, Christian Gachet ${ }^{5}$, Rebecca Hills ${ }^{6}$, Robert G. Humphries ${ }^{7}$, Kazu Inoue ${ }^{8}$, Kenneth A. Jacobson ${ }^{9}$, Charles Kennedy ${ }^{10}$, Brian F. King ${ }^{11}$, Davide Lecca ${ }^{1}$, Christa E. Müller ${ }^{12}$, Maria Teresa Miras-Portugal ${ }^{13}$, Vera Ralevic ${ }^{14}$ and Gary A. Weisman ${ }^{15}$

1. University of Milan, Italy

2. Université Libre de Bruxelles, Belgium

3. University of North Carolina, USA

4. Autonomic Neuroscience Centre, University College London, UK

5. INSERM, France

6. University of Edinburgh, UK

7. AstraZeneca, UK

8. University of Kyushu, Japan

9. National Institutes of Health, USA

10. University of Strathclyde, UK

11. University College London, UK

12. Universität Bonn, Germany

13. Universidad Complutense de Madrid, Spain

14. University of Nottingham, UK

15. University of Missouri, USA

\begin{abstract}
P2Y receptors (nomenclature as agreed by the NC-IUPHAR Subcommittee on P2Y Receptors $[3, \mathbf{5}, \mathbf{1 9 2}]$ ) are activated by the endogenous ligands ATP, ADP, uridine triphosphate, uridine diphosphate and UDP-glucose. The relationship of many of the cloned receptors to endogenously expressed receptors is not yet established and so it might be appropriate to use wording such as 'uridine triphosphate-preferring (or ATP-, etc.) P2Y receptor' or 'P2Y ${ }_{1}$-like', etc., until further, as yet undefined, corroborative criteria can be applied [47, 110, 190, 383, 396]. Clinically used drugs acting on these receptors include the dinucleoside polyphosphate diquafosol, agonist of the $\mathrm{P}_{2} \mathrm{Y}_{2}$ receptor subtype, approved in Japan for the management of dry eye disease [241], and the P2Y 12 receptor antagonists prasugrel, ticagrelor and cangrelor, all approved as antiplatelet drugs [53, 323].
\end{abstract}

\section{Contents}

This is a citation summary for P2Y receptors in the Guide to Pharmacology database (GtoPdb). It exists purely as an adjunct to the database to facilitate the recognition of citations to and from the database by citation analyzers. Readers will almost certainly want to visit the relevant sections of the database which are given here under database links.

GtoPdb is an expert-driven guide to pharmacological targets and the substances that act on them. GtoPdb is a reference work which is most usefully represented as an on-line database. As in any publication this work should be appropriately cited, and the papers it cites should also be recognized. This document provides a citation for the relevant parts of the database, and also provides a reference list for the research cited by those parts. For further details see [44].

Please note that the database version for the citations given in GtoPdb are to the most recent preceding version in which the family or its subfamilies and targets were substantially changed. The links below are to the current version. If you need to consult the cited version, rather than the most recent version, please contact the GtoPdb curators.

\section{Database links}


P2Y receptors

https://www.guidetopharmacology.org/GRAC/FamilyDisplayForward?familyId=52

Introduction to $\mathrm{P} 2 \mathrm{Y}$ receptors

https://www.guidetopharmacology.org/GRAC/FamilyIntroductionForward?familyId=52

Receptors

$\mathrm{P}_{1} \mathrm{Y}_{1}$ receptor

https://www.guidetopharmacology.org/GRAC/ObjectDisplayForward?objectId=323

$\mathrm{P}_{2} \mathrm{Y}_{2}$ receptor

https://www.guidetopharmacology.org/GRAC/ObjectDisplayForward?objectId=324

$\mathrm{P}_{4} \mathrm{Y}_{4}$ receptor

https://www.guidetopharmacology.org/GRAC/ObjectDisplayForward?objectId=325

$\mathrm{P}_{2} \mathrm{Y}_{6}$ receptor

https://www.guidetopharmacology.org/GRAC/ObjectDisplayForward?objectId=326

$\mathrm{P}_{2} \mathrm{Y}_{11}$ receptor

https://www.guidetopharmacology.org/GRAC/ObjectDisplayForward?objectId=327

$\mathrm{P}_{2} \mathrm{Y}_{12}$ receptor

https://www.guidetopharmacology.org/GRAC/ObjectDisplayForward?objectId=328

$\mathrm{P}_{2} \mathrm{Y}_{13}$ receptor

https://www.guidetopharmacology.org/GRAC/ObjectDisplayForward?objectId=329

$\mathrm{P}_{2} \mathrm{Y}_{14}$ receptor

https://www.guidetopharmacology.org/GRAC/ObjectDisplayForward?objectId=330

\section{References}

1. (2006) Invited Lectures : Overviews Purinergic signalling: past, present and future. Purinergic Signal 2: 1-324 [PMID:18404494]

2. A-González N and Castrillo A. (2011) Liver X receptors as regulators of macrophage inflammatory and metabolic pathways. Biochim Biophys Acta 1812: 982-94 [PMID:21193033]

3. Abbracchio MP, Boeynaems JM, Barnard EA, Boyer JL, Kennedy C, Miras-Portugal MT, King BF, Gachet C, Jacobson KA and Weisman GA et al.. (2003) Characterization of the UDP-glucose receptor (re-named here the P2Y14 receptor) adds diversity to the P2Y receptor family. Trends Pharmacol Sci 24: 52-5 [PMID:12559763]

4. Abbracchio MP and Burnstock G. (1994) Purinoceptors: are there families of P2X and P2Y purinoceptors? Pharmacol Ther 64: 445-75 [PMID:7724657]

5. Abbracchio MP, Burnstock G, Boeynaems JM, Barnard EA, Boyer JL, Kennedy C, Knight GE, Fumagalli M, Gachet C and Jacobson KA et al.. (2006) International Union of Pharmacology LVIII: update on the P2Y G protein-coupled nucleotide receptors: from molecular mechanisms and pathophysiology to therapy. Pharmacol Rev 58: 281-341 [PMID:16968944]

6. Abbracchio MP, Burnstock G, Boeynaems JM, Barnard EA, Boyer JL, Kennedy C, Miras-Portugal MT, King BF, Gachet C and Jacobson KA et al.. (2005) The recently deorphanized GPR80 (GPR99) proposed to be the P2Y15 receptor is not a genuine P2Y receptor. Trends Pharmacol Sci 26: 8-9 [PMID:15629198]

7. Ahn JS, Camden JM, Schrader AM, Redman RS and Turner JT. (2000) Reversible regulation of $\mathrm{P} 2 \mathrm{Y}(2)$ nucleotide receptor expression in the duct-ligated rat submandibular gland. Am J Physiol, Cell Physiol 279: C286-94 [PMID:10912994]

8. Alvarenga EC, Rodrigues R, Caricati-Neto A, Silva-Filho FC, Paredes-Gamero EJ and Ferreira AT. (2010) Low-intensity pulsed ultrasound-dependent osteoblast proliferation occurs by via activation of the P2Y receptor: role of the P2Y1 receptor. Bone 46: 355-62 [PMID:19781676]

9. Amisten S, Braun OO, Johansson L, Ridderstråle M, Melander O and Erlinge D. (2008) The P2Y 13 Met-158-Thr polymorphism, which is in linkage disequilibrium with the P2Y 12 locus, is not associated with acute myocardial infarction. PLOS ONE 3: e1462 [PMID:18213371]

10. Amisten S, Meidute-Abaraviciene S, Tan C, Olde B, Lundquist I, Salehi A and Erlinge D. (2010) ADP mediates inhibition of insulin secretion by activation of P2Y13 receptors in mice. Diabetologia 53: 1927-34 [PMID:20526761]

11. Amisten S, Melander O, Wihlborg AK, Berglund G and Erlinge D. (2007) Increased risk of acute myocardial infarction and elevated levels of C-reactive protein in carriers of the Thr-87 variant of the ATP receptor P2Y11. Eur Heart J 28: 13-8 [PMID:17135283]

12. Andre P, Delaney SM, LaRocca T, Vincent D, DeGuzman F, Jurek M, Koller B, Phillips DR and Conley PB. (2003) P2Y12 regulates platelet adhesion/activation, thrombus growth, and thrombus stability in injured arteries. J Clin Invest 112: 398-406 [PMID:12897207]

13. Arellano RO, Martínez-Torres A and Garay E. (2002) Ionic currents activated via purinergic receptors in the cumulus cell-enclosed mouse oocyte. Biol Reprod 67: 837-46 [PMID:12193392]

14. Arthur DB, Akassoglou K and Insel PA. (2005) P2Y2 receptor activates nerve growth factor/TrkA signaling to enhance neuronal differentiation. Proc Natl Acad Sci USA 102: 19138-43 
[PMID:16365320]

15. Arthur DB, Akassoglou K and Insel PA. (2006) P2Y2 and TrkA receptors interact with Src family kinase for neuronal differentiation. Biochem Biophys Res Commun 347: 678-82 [PMID:16842754]

16. Arthur DB, Georgi S, Akassoglou K and Insel PA. (2006) Inhibition of apoptosis by P2Y2 receptor activation: novel pathways for neuronal survival. J Neurosci 26: 3798-804 [PMID:16597733]

17. Ayyanathan K, Webbs TE, Sandhu AK, Athwal RS, Barnard EA and Kunapuli SP. (1996) Cloning and chromosomal localization of the human P2Y1 purinoceptor. Biochem Biophys Res Commun 218: 783-8 [PMID:8579591]

18. Azran S, Förster D, Danino O, Nadel Y, Reiser G and Fischer B. (2013) Highly efficient biocompatible neuroprotectants with dual activity as antioxidants and P2Y receptor agonists. $J$ Med Chem 56: 4938-52 [PMID:23751098]

19. Bach P, Boström J, Brickmann K, Burgess LE, Clarke D, Groneberg RD, Harvey DM, Laird ER, O'Sullivan M and Zetterberg F. (2013) 5-alkyl-1,3-oxazole derivatives of 6-amino-nicotinic acids as alkyl ester bioisosteres are antagonists of the P2Y12 receptor. Future Med Chem 5: 2037-56 [PMID:24215345]

20. Bagchi S, Liao Z, Gonzalez FA, Chorna NE, Seye CI, Weisman GA and Erb L. (2005) The P2Y2 nucleotide receptor interacts with alphav integrins to activate Go and induce cell migration. $J$ Biol Chem 280: 39050-7 [PMID:16186116]

21. Bailey MA, Imbert-Teboul M, Turner C, Srai SK, Burnstock G and Unwin RJ. (2001) Evidence for basolateral P2Y(6) receptors along the rat proximal tubule: functional and molecular characterization. J Am Soc Nephrol 12: 1640-7 [PMID:11461936]

22. Balduini A, Di Buduo CA, Malara A, Lecchi A, Rebuzzini P, Currao M, Pallotta I, Jakubowski JA and Cattaneo M. (2012) Constitutively released adenosine diphosphate regulates proplatelet formation by human megakaryocytes. Haematologica 97: 1657-65 [PMID:22689668]

23. Balogh J, Wihlborg AK, Isackson H, Joshi BV, Jacobson KA, Arner A and Erlinge D. (2005) Phospholipase C and cAMP-dependent positive inotropic effects of ATP in mouse cardiomyocytes via P2Y11-like receptors. J Mol Cell Cardiol 39: 223-30 [PMID:15893764]

24. Baqi Y, Atzler K, Köse M, Glänzel M and Müller CE. (2009) High-affinity, non-nucleotide-derived competitive antagonists of platelet P2Y12 receptors. J Med Chem 52: 3784-93 [PMID:19463000]

25. Bar I, Guns PJ, Metallo J, Cammarata D, Wilkin F, Boeynams JM, Bult H and Robaye B. (2008) Knockout mice reveal a role for P2Y6 receptor in macrophages, endothelial cells, and vascular smooth muscle cells. Mol Pharmacol 74: 777-84 [PMID:18523137]

26. Barn K and Steinhubl SR. (2012) A brief review of the past and future of platelet P2Y12 antagonist. Coron Artery Dis 23: 368-74 [PMID:22735090]

27. Barragan P, Bouvier JL, Roquebert PO, Macaluso G, Commeau P, Comet B, Lafont A, Camoin L, Walter U and Eigenthaler M. (2003) Resistance to thienopyridines: clinical detection of coronary stent thrombosis by monitoring of vasodilator-stimulated phosphoprotein phosphorylation. Catheter Cardiovasc Interv 59: 295-302 [PMID:12822144]

28. Barrett MO, Sesma JI, Ball CB, Jayasekara PS, Jacobson KA, Lazarowski ER and Harden TK. (2013) A Selective High-Affinity Antagonist of the P2Y14 Receptor Inhibits UDP-GlucoseStimulated Chemotaxis of Human Neutrophils. Mol Pharmacol 84: 41-9 [PMID:23592514]

29. Bartoo AC, Nelson MT and Mawe GM. (2008) ATP induces guinea pig gallbladder smooth muscle excitability via the P2Y4 receptor and COX-1 activity. Am J Physiol Gastrointest Liver Physiol 294: G1362-8 [PMID:18436624]

30. Bassil AK, Bourdu S, Townson KA, Wheeldon A, Jarvie EM, Zebda N, Abuin A, Grau E, Livi GP and Punter L et al.. (2009) UDP-glucose modulates gastric function through P2Y14 receptordependent and -independent mechanisms. Am J Physiol Gastrointest Liver Physiol 296: G923-30 [PMID:19164486]

31. Belete HA, Hubmayr RD, Wang S and Singh RD. (2011) The role of purinergic signaling on deformation induced injury and repair responses of alveolar epithelial cells. PLOS ONE 6: e27469 [PMID:22087324]

32. Belous AE, Jones CM, Wakata A, Knox CD, Nicoud IB, Pierce J and Chari RS. (2006) Mitochondrial calcium transport is regulated by P2Y1- and P2Y2-like mitochondrial receptors. $J$ Cell Biochem 99: 1165-1174 [PMID:16795051]

33. Besada P, Shin DH, Costanzi S, Ko H, Mathé C, Gagneron J, Gosselin G, Maddileti S, Harden TK and Jacobson KA. (2006) Structure-activity relationships of uridine 5'-diphosphate analogues at the human P2Y6 receptor. J Med Chem 49: 5532-43 [PMID:16942026]

34. Bianco F, Fumagalli M, Pravettoni E, D'Ambrosi N, Volonté C, Matteoli M, Abbracchio MP and Verderio C. (2005) Pathophysiological roles of extracellular nucleotides in glial cells: differential expression of purinergic receptors in resting and activated microglia. Brain Res Brain Res Rev 48: 144-156 [PMID:15850653]

35. Blom D, Yamin TT, Champy MF, Selloum M, Bedu E, Carballo-Jane E, Gerckens L, Luell S, Meurer R and Chin J et al.. (2010) Altered lipoprotein metabolism in P2Y(13) knockout mice. Biochim Biophys Acta 1801: 1349-60 [PMID:20817122] 
36. Bodor ET, Waldo GL, Hooks SB, Corbitt J, Boyer JL and Harden TK. (2003) Purification and functional reconstitution of the human P2Y12 receptor. Mol Pharmacol 64: 1210-6 [PMID:14573771]

37. Bogdanov YD, Dale L, King BF, Whittock N and Burnstock G. (1997) Early expression of a novel nucleotide receptor in the neural plate of Xenopus embryos. J Biol Chem 272: 12583-90 [PMID:9139711]

38. Bogdanov YD, Wildman SS, Clements MP, King BF and Burnstock G. (1998) Molecular cloning and characterization of rat P2Y4 nucleotide receptor. Br J Pharmacol 124: 428-30 [PMID:9647463]

39. Boyer JL, Adams M, Ravi RG, Jacobson KA and Harden TK. (2002) 2-Chloro N(6)-methyl-(N)methanocarba-2'-deoxyadenosine-3',5'-bisphosphate is a selective high affinity P2Y(1) receptor antagonist. Br J Pharmacol 135: 2004-2010 [PMID:11959804]

40. Boyer JL, Delaney SM, Villanueva D and Harden TK. (2000) A molecularly identified P2Y receptor simultaneously activates phospholipase $\mathrm{C}$ and inhibits adenylyl cyclase and is nonselectively activated by all nucleoside triphosphates. Mol Pharmacol 57: 805-10 [PMID:10727529]

41. Boyer JL, Romero-Avila T, Schachter JB and Harden TK. (1996) Identification of competitive antagonists of the P2Y1 receptor. Mol Pharmacol 50: 1323-9 [PMID:8913364]

42. Boyer JL, Waldo GL and Harden TK. (1997) Molecular cloning and expression of an avian G protein-coupled P2Y receptor. Mol Pharmacol 52: 928-34 [PMID:9415702]

43. Brunschweiger A and Müller CE. (2006) P2 receptors activated by uracil nucleotides--an update. Curr Med Chem 13: 289-312 [PMID:16475938]

44. Buneman P, Christie G, Davies JA, Dimitrellou R, Harding SD, Pawson AJ, Sharman JL and Wu Y. (2020) Why data citation isn't working, and what to do about it Database 2020 [PMID:32367113]

45. Burnstock G. (2017) Purinergic Signalling: Therapeutic Developments. Front Pharmacol 8: 661 [PMID:28993732]

46. Burnstock G. (1997) The past, present and future of purine nucleotides as signalling molecules. Neuropharmacology 36: 1127-39 [PMID:9364468]

47. Burnstock G and Verkhratsky A. (2012) Purinergic signalling and the nervous system. Springer: 1-715

48. Burnstock GDobson. (1998) The G protein-coupled P2Y receptors. In Cardiovascular Biology of Purines Edited by Burnstock G: Kluwer Academic Publishers: 187-205 [ISBN: 0792383346]

49. Buvinic S, Bravo-Zehnder M, Boyer JL, Huidobro-Toro JP and González A. (2007) Nucleotide P2Y1 receptor regulates EGF receptor mitogenic signaling and expression in epithelial cells. $J$ Cell Sci 120: 4289-301 [PMID:18057028]

50. Buvinic S, Briones R and Huidobro-Toro JP. (2002) P2Y(1) and P2Y(2) receptors are coupled to the NO/cGMP pathway to vasodilate the rat arterial mesenteric bed. Br J Pharmacol 136: 847-56 [PMID:12110609]

51. Büscher R, Hoerning A, Patel HH, Zhang S, Arthur DB, Grasemann H, Ratjen F and Insel PA. (2006) P2Y2 receptor polymorphisms and haplotypes in cystic fibrosis and their impact on Ca2+ influx. Pharmacogenet Genomics 16: 199-205 [PMID:16495779]

52. Camden JM, Schrader AM, Camden RE, González FA, Erb L, Seye CI and Weisman GA. (2005) P2Y2 nucleotide receptors enhance alpha-secretase-dependent amyloid precursor protein processing. J Biol Chem 280: 18696-702 [PMID:15778502]

53. Capodanno D, Ferreiro JL and Angiolillo DJ. (2013) Antiplatelet therapy: new pharmacological agents and changing paradigms. J Thromb Haemost 11 Suppl 1: 316-29 [PMID:23809135]

54. Caporali F, Capecchi PL, Gamberucci A, Lazzerini PE, Pompella G, Natale M, Lorenzini S, Selvi E, Galeazzi M and Laghi Pasini F. (2008) Human rheumatoid synoviocytes express functional P2X7 receptors. J Mol Med 86: 937-949 [PMID:18545980]

55. Carrasquero LM, Delicado EG, Bustillo D, Gutiérrez-Martín Y, Artalejo AR and Miras-Portugal MT. (2009) P2X7 and P2Y13 purinergic receptors mediate intracellular calcium responses to BzATP in rat cerebellar astrocytes. J Neurochem 110: 879-89 [PMID:19457067]

56. Carter RL, Fricks IP, Barrett MO, Burianek LE, Zhou Y, Ko H, Das A, Jacobson KA, Lazarowski ER and Harden TK. (2009) Quantification of Gi-mediated inhibition of adenylyl cyclase activity reveals that UDP is a potent agonist of the human P2Y14 receptor. Mol Pharmacol 76: 1341-8 [PMID:19759354]

57. Castro E, Pintor J and Miras-Portugal MT. (1992) Ca(2+)-stores mobilization by diadenosine tetraphosphate, Ap4A, through a putative $\mathrm{P} 2 \mathrm{Y}$ purinoceptor in adrenal chromaffin cells. $\mathrm{Br} \mathrm{J}$ Pharmacol 106: 833-7 [PMID:1393282]

58. Cattaneo M and Gachet C. (1999) ADP receptors and clinical bleeding disorders. Arterioscler Thromb Vasc Biol 19: 2281-5 [PMID:10521355]

59. Cattaneo M, Lecchi A, Ohno M, Joshi BV, Besada P, Tchilibon S, Lombardi R, Bischofberger N, Harden TK and Jacobson KA. (2004) Antiaggregatory activity in human platelets of potent antagonists of the P2Y 1 receptor. Biochem Pharmacol 68: 1995-2002 [PMID:15476670] 
60. Cattaneo M, Lecchi A, Randi AM, McGregor JL and Mannucci PM. (1992) Identification of a new congenital defect of platelet function characterized by severe impairment of platelet responses to adenosine diphosphate. Blood 80: 2787-96 [PMID:1333302]

61. Cattaneo M, Zighetti ML, Lombardi R, Martinez C, Lecchi A, Conley PB, Ware J and Ruggeri ZM. (2003) Molecular bases of defective signal transduction in the platelet P2Y12 receptor of a patient with congenital bleeding. Proc Natl Acad Sci USA 100: 1978-83 [PMID:12578987]

62. Cavallari U, Trabetti E, Malerba G, Biscuola M, Girelli D, Olivieri O, Martinelli N, Angiolillo DJ, Corrocher R and Pignatti PF. (2007) Gene sequence variations of the platelet P2Y12 receptor are associated with coronary artery disease. BMC Med Genet 8: 59 [PMID:17803810]

63. Cekic C and Linden J. (2016) Purinergic regulation of the immune system. Nat Rev Immunol 16: 177-92 [PMID:26922909]

64. Ceruti S, Fumagalli M, Villa G, Verderio C and Abbracchio MP. (2008) Purinoceptor-mediated calcium signaling in primary neuron-glia trigeminal cultures. Cell Calcium 43: 576-90 [PMID:18031810]

65. Chadet S, Ivanes F, Benoist L, Salmon-Gandonnière C, Guibon R, Velge-Roussel F, Babuty D, Baron C, Roger S and Angoulvant D. (2015) Hypoxia/Reoxygenation Inhibits P2Y11 Receptor Expression and Its Immunosuppressive Activity in Human Dendritic Cells. J Immunol 195: 65160 [PMID:26078273]

66. Chambers JK, Macdonald LE, Sarau HM, Ames RS, Freeman K, Foley JJ, Zhu Y, McLaughlin MM, Murdock P and McMillan L et al.. (2000) A G protein-coupled receptor for UDP-glucose. $J$ Biol Chem 275: 10767-71 [PMID:10753868]

67. Chang H, Yanachkov IB, Dix EJ, Li YF, Barnard MR, Wright GE, Michelson AD and Frelinger 3rd AL. (2012) Modified diadenosine tetraphosphates with dual specificity for P2Y1 and P2Y12 are potent antagonists of ADP-induced platelet activation. J Thromb Haemost 10: 2573-80 [PMID:23083103]

68. Chang K, Hanaoka K, Kumada M and Takuwa Y. (1995) Molecular cloning and functional analysis of a novel $\mathrm{P}_{2}$ nucleotide receptor. J Biol Chem 270: 26152-26158 [PMID:7592819]

69. Charlton ME, Williams AS, Fogliano M, Sweetnam PM and Duman RS. (1997) The isolation and characterization of a novel G protein-coupled receptor regulated by immunologic challenge. Brain Res 764: 141-8 [PMID:9295203]

70. Chen D, Wang W, Guo W, Yu Q, Burnstock G, He C, Xiang Z and Zheng H. (2011) Expression of $\mathrm{P} 2 \mathrm{Y}(6)$ receptors in the developing mouse skeletal muscle and after injury and repair. J Anat 218: 643-51 [PMID:21413988]

71. Chen Y, Corriden R, Inoue Y, Yip L, Hashiguchi N, Zinkernagel A, Nizet V, Insel PA and Junger WG. (2006) ATP release guides neutrophil chemotaxis via P2Y2 and A3 receptors. Science 314: 1792-5 [PMID:17170310]

72. Cheung KK, Ryten M and Burnstock G. (2003) Abundant and dynamic expression of G proteincoupled P2Y receptors in mammalian development. Dev Dyn 228: 254-66 [PMID:14517997]

73. Chhatriwala M, Ravi RG, Patel RI, Boyer JL, Jacobson KA and Harden TK. (2004) Induction of novel agonist selectivity for the ADP-activated P2Y1 receptor versus the ADP-activated P2Y12 and P2Y13 receptors by conformational constraint of an ADP analog. J Pharmacol Exp Ther 311: 1038-43 [PMID:15345752]

74. Choi JY, Shin JH, Kim JL, Jung SH, Son EJ, Song MH, Kim SH and Yoon JH. (2005) P2Y2 agonist induces mucin secretion via $\mathrm{Ca} 2+-$ and inositol 1,4,5-triphosphate-dependent pathway in human middle ear epithelial cells. Hear Res 209: 24-31 [PMID:16139976]

75. Choi RC, Simon J, Tsim KW and Barnard EA. (2008) Constitutive and agonist-induced dimerizations of the P2Y1 receptor: relationship to internalization and scaffolding. J Biol Chem 283: 11050-63 [PMID:18270199]

76. Clarke LL, Harline MC, Gawenis LR, Walker NM, Turner JT and Weisman GA. (2000) Extracellular UTP stimulates electrogenic bicarbonate secretion across CFTR knockout gallbladder epithelium. Am J Physiol Gastrointest Liver Physiol 279: G132-8 [PMID:10898755]

77. Communi D, Gonzalez NS, Detheux M, Brézillon S, Lannoy V, Parmentier M and Boeynaems JM. (2001) Identification of a novel human ADP receptor coupled to G(i). J Biol Chem 276: 41479-85 [PMID:11546776]

78. Communi D, Govaerts C, Parmentier M and Boeynaems JM. (1997) Cloning of a human purinergic P2Y receptor coupled to phospholipase C and adenylyl cyclase. J Biol Chem 272: 31969-73 [PMID:9405388]

79. Communi D, Janssens R, Robaye B, Zeelis N and Boeynaems JM. (2000) Rapid up-regulation of P2Y messengers during granulocytic differentiation of HL-60 cells. FEBS Lett 475: 39-42 [PMID:10854854]

80. Communi D, Parmentier M and Boeynaems JM. (1996) Cloning, functional expression and tissue distribution of the human P2Y6 receptor. Biochem Biophys Res Commun 222: 303-8 [PMID:8670200]

81. Communi D, Pirotton S, Parmentier M and Boeynaems JM. (1995) Cloning and functional expression of a human uridine nucleotide receptor. J Biol Chem 270: 30849-30852 
[PMID:8537336]

82. Communi D, Robaye B and Boeynaems JM. (1999) Pharmacological characterization of the human P2Y11 receptor. Br J Pharmacol 128: 1199-206 [PMID:10578132]

83. Communi D, Suarez-Huerta N, Dussossoy D, Savi P and Boeynaems JM. (2001) Cotranscription and intergenic splicing of human P2Y11 and SSF1 genes. J Biol Chem 276: 16561-6 [PMID:11278528]

84. Costanzi S, Joshi BV, Maddileti S, Mamedova L, Gonzalez-Moa MJ, Marquez VE, Harden TK and Jacobson KA. (2005) Human P2Y(6) receptor: molecular modeling leads to the rational design of a novel agonist based on a unique conformational preference. J Med Chem 48: 8108-11 [PMID:16366591]

85. Costanzi S, Mamedova L, Gao ZG and Jacobson KA. (2004) Architecture of P2Y nucleotide receptors: structural comparison based on sequence analysis, mutagenesis, and homology modeling. J Med Chem 47: 5393-5404 [PMID:15481977]

86. Costanzi S, Santhosh Kumar T, Balasubramanian R, Kendall Harden T and Jacobson KA. (2012) Virtual screening leads to the discovery of novel non-nucleotide $\mathrm{P}_{2} \mathrm{Y}_{1}$ receptor antagonists. Bioorg Med Chem 20: 5254-61 [PMID:22831801]

87. Coutinho-Silva R, Ojcius DM, Górecki DC, Persechini PM, Bisaggio RC, Mendes AN, Marks J, Burnstock G and Dunn PM. (2005) Multiple P2X and P2Y receptor subtypes in mouse J774, spleen and peritoneal macrophages. Biochem Pharmacol 69: 641-55 [PMID:15670583]

88. Cressman VL, Lazarowski E, Homolya L, Boucher RC, Koller BH and Grubb BR. (1999) Effect of loss of $\mathrm{P} 2 \mathrm{Y}(2)$ receptor gene expression on nucleotide regulation of murine epithelial $\mathrm{Cl}(-)$ transport. J Biol Chem 274: 26461-8 [PMID:10473606]

89. Cunningham MR, Nisar SP, Cooke AE, Emery ED and Mundell SJ. (2013) Differential endosomal sorting of a novel P2Y12 purinoreceptor mutant. Traffic 14: 585-98 [PMID:23387322]

90. Cusack NJ and Hourani SM. (1982) Adenosine 5-diphosphate antagonists and human platelets: no evidence that aggregation and inhibition of stimulated adenylate cyclase are mediated by different receptors. Br J Pharmacol 76: 221-7 [PMID:6282375]

91. Daly ME, Dawood BB, Lester WA, Peake IR, Rodeghiero F, Goodeve AC, Makris M, Wilde JT, Mumford AD and Watson SP et al.. (2009) Identification and characterization of a novel P2Y 12 variant in a patient diagnosed with type 1 von Willebrand disease in the European MCMDM1VWD study. Blood 113: 4110-3 [PMID:19237732]

92. Das A, Ko H, Burianek LE, Barrett MO, Harden TK and Jacobson KA. (2010) Human P2Y(14) receptor agonists: truncation of the hexose moiety of uridine-5'-diphosphoglucose and its replacement with alkyl and aryl groups. J Med Chem 53: 471-80 [PMID:19902968]

93. Das A, Zhou Y, Ivanov AA, Carter RL, Harden TK and Jacobson KA. (2009) Enhanced potency of nucleotide-dendrimer conjugates as agonists of the P2Y14 receptor: multivalent effect in G protein-coupled receptor recognition. Bioconjug Chem 20: 1650-9 [PMID:19572637]

94. Davenport RJ, Diaz P, Galvin FC, Lloyd S, Mack SR, Owens R, Sabin V and Wynn J. (2007) Novel nucleotide triphosphates as potent P2Y2 agonists with enhanced stability over UTP. Bioorg Med Chem Lett 17: 558-61 [PMID:17079144]

95. Davis CW and Lazarowski E. (2008) Coupling of airway ciliary activity and mucin secretion to mechanical stresses by purinergic signaling. Respir Physiol Neurobiol 163: 208-13 [PMID:18635403]

96. Degagné E, Grbic DM, Dupuis AA, Lavoie EG, Langlois C, Jain N, Weisman GA, Sévigny J and Gendron FP. (2009) P2Y2 receptor transcription is increased by NF-kappa B and stimulates cyclooxygenase-2 expression and PGE2 released by intestinal epithelial cells. J Immunol 183: 4521-9 [PMID:19734210]

97. del Puerto A, Díaz-Hernández JI, Tapia M, Gomez-Villafuertes R, Benitez MJ, Zhang J, MirasPortugal MT, Wandosell F, Díaz-Hernández M and Garrido JJ. (2012) Adenylate cyclase 5 coordinates the action of ADP, P2Y1, P2Y13 and ATP-gated P2X7 receptors on axonal elongation. J Cell Sci 125: 176-88 [PMID:22250198]

98. Deterding R, Retsch-Bogart G, Milgram L, Gibson R, Daines C, Zeitlin PL, Milla C, Marshall B, Lavange L and Engels J et al.. (2005) Safety and tolerability of denufosol tetrasodium inhalation solution, a novel P2Y2 receptor agonist: results of a phase 1/phase 2 multicenter study in mild to moderate cystic fibrosis. Pediatr Pulmonol 39: 339-48 [PMID:15704203]

99. Ding Z, Tuluc F, Bandivadekar KR, Zhang L, Jin J and Kunapuli SP. (2005) Arg333 and Arg334 in the $\mathrm{COOH}$ terminus of the human P2Y1 receptor are crucial for Gq coupling. Am J Physiol, Cell Physiol 288: C559-67 [PMID:15509659]

100. Dixon CJ, Bowler WB, Littlewood-Evans A, Dillon JP, Bilbe G, Sharpe GR and Gallagher JA. (1999) Regulation of epidermal homeostasis through P2Y2 receptors. BrJ Pharmacol 127: 16806 [PMID:10455326]

101. Douglass JG, Patel RI, Yerxa BR, Shaver SR, Watson PS, Bednarski K, Plourde R, Redick CC, Brubaker K and Jones AC et al.. (2008) Lipophilic modifications to dinucleoside polyphosphates and nucleotides that confer antagonist properties at the platelet P2Y12 receptor. J Med Chem 51: 1007-25 [PMID:18232657] 
102. Ecke D, Hanck T, Tulapurkar ME, Schäfer R, Kassack M, Stricker R and Reiser G. (2008) Hetero-oligomerization of the P2Y11 receptor with the P2Y1 receptor controls the internalization and ligand selectivity of the P2Y11 receptor. Biochem J 409: 107-16 [PMID:17824841]

103. El-Tayeb A, Griessmeier KJ and Müller CE. (2005) Synthesis and preliminary evaluation of [3H]PSB-0413, a selective antagonist radioligand for platelet P2Y12 receptors. Bioorg Med Chem Lett 15: 5450-2 [PMID:16213725]

104. El-Tayeb A, Qi A and Müller CE. (2006) Synthesis and structure-activity relationships of uracil nucleotide derivatives and analogues as agonists at human P2Y2, P2Y4, and P2Y6 receptors. $J$ Med Chem 49: 7076-87 [PMID:17125260]

105. El-Tayeb A, Qi A, Nicholas RA and Müller CE. (2011) Structural modifications of UMP, UDP, and UTP leading to subtype-selective agonists for P2Y2, P2Y4, and P2Y6 receptors. J Med Chem 54: 2878-90 [PMID:21417463]

106. Elliott MR, Chekeni FB, Trampont PC, Lazarowski ER, Kadl A, Walk SF, Park D, Woodson RI, Ostankovich M and Sharma P et al.. (2009) Nucleotides released by apoptotic cells act as a findme signal to promote phagocytic clearance. Nature 461: 282-6 [PMID:19741708]

107. Ennion SJ, Powell AD and Seward EP. (2004) Identification of the P2Y(12) receptor in nucleotide inhibition of exocytosis from bovine chromaffin cells. Mol Pharmacol 66: 601-11 [PMID:15322252]

108. Erb L, Garrad R, Wang Y, Quinn T, Turner JT and Weisman GA. (1995) Site-directed mutagenesis of P2U purinoceptors. Positively charged amino acids in transmembrane helices 6 and 7 affect agonist potency and specificity. J Biol Chem 270: 4185-8 [PMID:7876172]

109. Erb L, Lustig KD, Sullivan DM, Turner JT and Weisman GA. (1993) Functional expression and photoaffinity labeling of a cloned P2U purinergic receptor. Proc Natl Acad Sci USA 90: 1044953 [PMID:8248130]

110. Erlinge D. (2011) P2Y receptors in health and disease. Adv Pharmacol 61: 417-39 [PMID:21586366]

111. Erlinge D, Hou M, Webb TE, Barnard EA and Moller S. (1998) Phenotype changes of the vascular smooth muscle cell regulate P2 receptor expression as measured by quantitative RTPCR. Biochem Biophys Res Commun 248: 864-870 [PMID:9704019]

112. Espada S, Ortega F, Molina-Jijón E, Rojo AI, Pérez-Sen R, Pedraza-Chaverri J, Miras-Portugal MT and Cuadrado A. (2010) The purinergic P2Y(13) receptor activates the Nrf2/HO-1 axis and protects against oxidative stress-induced neuronal death. Free Radic Biol Med 49: 416-26 [PMID:20447456]

113. Evans DJ, Jackman LE, Chamberlain J, Crosdale DJ, Judge HM, Jetha K, Norman KE, Francis SE and Storey RF. (2009) Platelet P2Y(12) receptor influences the vessel wall response to arterial injury and thrombosis. Circulation 119: 116-22 [PMID:19103996]

114. Fabre AC, Malaval C, Ben Addi A, Verdier C, Pons V, Serhan N, Lichtenstein L, Combes G, Huby T and Briand F et al.. (2010) P2Y13 receptor is critical for reverse cholesterol transport. Hepatology 52: 1477-83 [PMID:20830789]

115. Fabre JE, Nguyen M, Latour A, Keifer JA, Audoly LP, Coffman TM and Koller BH. (1999) Decreased platelet aggregation, increased bleeding time and resistance to thromboembolism in P2Y1-deficient mice. Nat Med 5: 1199-202 [PMID:10502826]

116. Filippov AK, Brown DA and Barnard EA. (2000) The P2Y(1) receptor closes the N-type Ca(2+) channel in neurones, with both adenosine triphosphates and diphosphates as potent agonists. $\mathrm{Br}$ J Pharmacol 129: 1063-6 [PMID:10725253]

117. Filippov AK, Choi RC, Simon J, Barnard EA and Brown DA. (2006) Activation of P2Y1 nucleotide receptors induces inhibition of the M-type $\mathrm{K}+$ current in rat hippocampal pyramidal neurons. $J$ Neurosci 26: 9340-8 [PMID:16957090]

118. Fischer B, Boyer JL, Hoyle CH, Ziganshin AU, Brizzolara AL, Knight GE, Zimmet J, Burnstock G, Harden TK and Jacobson KA. (1993) Identification of potent, selective P2Y-purinoceptor agonists: structure-activity relationships for 2-thioether derivatives of adenosine 5'-triphosphate. J Med Chem 36: 3937-46 [PMID:8254622]

119. Fontana P, Dupont A, Gandrille S, Bachelot-Loza C, Reny JL, Aiach M and Gaussem P. (2003) Adenosine diphosphate-induced platelet aggregation is associated with P2Y12 gene sequence variations in healthy subjects. Circulation 108: 989-95 [PMID:12912815]

120. Fontana P, Gaussem P, Aiach M, Fiessinger JN, Emmerich J and Reny JL. (2003) P2Y12 H2 haplotype is associated with peripheral arterial disease: a case-control study. Circulation 108: 2971-3 [PMID:14662702]

121. Foster CJ, Prosser DM, Agans JM, Zhai Y, Smith MD, Lachowicz JE, Zhang FL, Gustafson E, Monsma Jr FJ and Wiekowski MT et al.. (2001) Molecular identification and characterization of the platelet ADP receptor targeted by thienopyridine antithrombotic drugs. J Clin Invest 107: 1591-8 [PMID:11413167]

122. Foster HR, Fuerst E, Lee TH, Cousins DJ and Woszczek G. (2013) Characterisation of P2Y(12) receptor responsiveness to cysteinyl leukotrienes. PLoS ONE 8: e58305 [PMID:23472176] 
123. Fredholm BB, Abbracchio MP, Burnstock G, Dubyak GR, Harden TK, Jacobson KA, Schwabe U and Williams M. (1997) Towards a revised nomenclature for P1 and P2 receptors. Trends Pharmacol Sci 18: 79-82 [PMID:9133776]

124. Freeman K, Tsui P, Moore D, Emson PC, Vawter L, Naheed S, Lane P, Bawagan H, Herrity N and Murphy K et al.. (2001) Cloning, pharmacology, and tissue distribution of G-protein-coupled receptor GPR105 (KIAA0001) rodent orthologs. Genomics 78: 124-8 [PMID:11735218]

125. Fricks IP, Carter RL, Lazarowski ER and Harden TK. (2009) Gi-dependent cell signaling responses of the human P2Y14 receptor in model cell systems. J Pharmacol Exp Ther 330: 162-8 [PMID:19339661]

126. Fricks IP, Maddileti S, Carter RL, Lazarowski ER, Nicholas RA, Jacobson KA and Harden TK. (2008) UDP is a competitive antagonist at the human P2Y14 receptor. J Pharmacol Exp Ther 325: 588-94 [PMID:18252808]

127. Fries JE, Goczalik IM, Wheeler-Schilling TH, Kohler K, Guenther E, Wolf S, Wiedemann P, Bringmann A, Reichenbach A and Francke M et al.. (2005) Identification of P2Y receptor subtypes in human muller glial cells by physiology, single cell RT-PCR, and immunohistochemistry. Invest Ophthalmol Vis Sci 46: 3000-7 [PMID:16043877]

128. Fujita T, Tozaki-Saitoh H and Inoue K. (2009) P2Y1 receptor signaling enhances neuroprotection by astrocytes against oxidative stress via IL-6 release in hippocampal cultures. Glia 57: 244-57 [PMID:18756525]

129. Fumagalli M, Brambilla R, D'Ambrosi N, Volonté C, Matteoli M, Verderio C and Abbracchio MP. (2003) Nucleotide-mediated calcium signaling in rat cortical astrocytes: Role of P2X and P2Y receptors. Glia 43: 218-203 [PMID:12898701]

130. Fumagalli M, Trincavelli L, Lecca D, Martini C, Ciana P and Abbracchio MP. (2004) Cloning, pharmacological characterisation and distribution of the rat G-protein-coupled P2Y(13) receptor. Biochem Pharmacol 68: 113-24 [PMID:15183123]

131. Gachet C. (2008) P2 receptors, platelet function and pharmacological implications. Thromb Haemost 99: 466-72 [PMID:18327393]

132. Gachet C and Hechler B. (2005) The platelet P2 receptors in thrombosis. Semin Thromb Hemost 31: 162-7 [PMID:15852219]

133. Gallagher CJ and Salter MW. (2003) Differential properties of astrocyte calcium waves mediated by P2Y1 and P2Y2 receptors. J Neurosci 23: 6728-39 [PMID:12890765]

134. Gao ZG, Ding Y and Jacobson KA. (2010) P2Y(13) receptor is responsible for ADP-mediated degranulation in RBL-2H3 rat mast cells. Pharmacol Res 62: 500-5 [PMID:20813187]

135. Gao ZG, Ding Y and Jacobson KA. (2010) UDP-glucose acting at P2Y14 receptors is a mediator of mast cell degranulation. Biochem Pharmacol 79: 873-9 [PMID:19896471]

136. Gao ZG, Mamedova L, Tchilibon S, Gross AS and Jacobson KA. (2004) 2,2'-Pyridylisatogen tosylate antagonizes P2Y1 receptor signaling without affecting nucleotide binding. Biochem Pharmacol 68: 231-7 [PMID:15193995]

137. Gao ZG, Wei Q, Jayasekara MP and Jacobson KA. (2013) The role of P2Y(14) and other P2Y receptors in degranulation of human LAD2 mast cells. Purinergic Signal 9: 31-40 [PMID:22825617]

138. Gauthier JY, Belley M, Deschênes D, Fournier JF, Gagné S, Gareau Y, Hamel M, Hénault M, Hyjazie H and Kargman S et al.. (2011) The identification of 4,7-disubstituted naphthoic acid derivatives as UDP-competitive antagonists of P2Y14. Bioorg Med Chem Lett 21: 2836-9 [PMID:21507640]

139. Gayle S and Burnstock G. (2005) Immunolocalisation of P2X and P2Y nucleotide receptors in the rat nasal mucosa. Cell Tissue Res 319: 27-36 [PMID:15558320]

140. Geary C, Akinbi H, Korfhagen T, Fabre JE, Boucher R and Rice W. (2005) Increased susceptibility of purinergic receptor-deficient mice to lung infection with Pseudomonas aeruginosa. Am J Physiol Lung Cell Mol Physiol 289: L890-5 [PMID:16024720]

141. Ghanem E, Robaye B, Leal T, Leipziger J, Van Driessche W, Beauwens R and Boeynaems JM. (2005) The role of epithelial P2Y2 and P2Y4 receptors in the regulation of intestinal chloride secretion. Br J Pharmacol 146: 364-9 [PMID:16056234]

142. Giannattasio G, Ohta S, Boyce JR, Xing W, Balestrieri B and Boyce JA. (2011) The purinergic G protein-coupled receptor 6 inhibits effector T cell activation in allergic pulmonary inflammation. J Immunol 187: 1486-95 [PMID:21724990]

143. Giaroni C, Knight GE, Ruan HZ, Glass R, Bardini M, Lecchini S, Frigo G and Burnstock G. (2002) P2 receptors in the murine gastrointestinal tract. Neuropharmacology 43: 1313-23 [PMID:12527481]

144. Ginsburg-Shmuel T, Haas M, Grbic D, Arguin G, Nadel Y, Gendron FP, Reiser G and Fischer B. (2012) UDP made a highly promising stable, potent, and selective P2Y6-receptor agonist upon introduction of a boranophosphate moiety. Bioorg Med Chem 20: 5483-95 [PMID:22901672]

145. Gordon JL. (1986) Extracellular ATP: effects, sources and fate. Biochem J 233: 309-19 [PMID:3006665]

146. Govindan S, Taylor EJ and Taylor CW. (2010) Ca(2+) signalling by P2Y receptors in cultured rat 
aortic smooth muscle cells. Br J Pharmacol 160: 1953-62 [PMID:20649593]

147. Grbic DM, Degagné E, Langlois C, Dupuis AA and Gendron FP. (2008) Intestinal inflammation increases the expression of the P2Y6 receptor on epithelial cells and the release of CXC chemokine ligand 8 by UDP. J Immunol 180: 2659-68 [PMID:18250478]

148. Gretler DD, Conley PB, Andre P, Jurek M, Pandey A, Ronanko K, Leese PT, Hutchaleelaha A and Phillips DR. (2007) "First in human" experience with PRT060128, a new direct-acting, reversible, P2Y12 inhibitor for IV and oral use. J Am Coll Cardiol 49: 326

149. Greve H, Meis S, Kassack MU, Kehraus S, Krick A, Wright AD and König GM. (2007) New iantherans from the marine sponge Ianthella quadrangulata: novel agonists of the P2Y(11) receptor. J Med Chem 50: 5600-7 [PMID:17941622]

150. Grimm I, Messemer N, Stanke M, Gachet C and Zimmermann H. (2009) Coordinate pathways for nucleotide and EGF signaling in cultured adult neural progenitor cells. J Cell Sci 122: 252433 [PMID:19549686]

151. Gruenbacher G, Gander H, Dobler G, Rahm A, Klaver D and Thurnher M. (2021) The human G protein-coupled ATP receptor $\mathrm{P}_{2} \mathrm{Y}_{11}$ is a target for anti-inflammatory strategies. Br J Pharmacol 178: 1541-1555 [PMID:33463722]

152. Guay D, Beaulieu C, Belley M, Crane SN, DeLuca J, Gareau Y, Hamel M, Henault M, Hyjazie H and Kargman S et al.. (2011) Synthesis and SAR of pyrimidine-based, non-nucleotide P2Y14 receptor antagonists. Bioorg Med Chem Lett 21: 2832-5 [PMID:21507642]

153. Gulbransen BD and Sharkey KA. (2009) Purinergic neuron-to-glia signaling in the enteric nervous system. Gastroenterology 136: 1349-58 [PMID:19250649]

154. Guns PJ, Hendrickx J, Van Assche T, Fransen P and Bult H. (2010) P2Y receptors and atherosclerosis in apolipoprotein E-deficient mice. Br J Pharmacol 159: 326-36 [PMID:20050854]

155. Guns PJ, Van Assche T, Fransen P, Robaye B, Boeynaems JM and Bult H. (2006) Endotheliumdependent relaxation evoked by ATP and UTP in the aorta of P2Y2-deficient mice. $\mathrm{BrJ}$ Pharmacol 147: 569-74 [PMID:16415908]

156. Gödecke S, Decking UK, Gödecke A and Schrader J. (1996) Cloning of the rat P2u receptor and its potential role in coronary vasodilation. Am J Physiol 270: C570-7 [PMID:8779921]

157. Haas M, Ginsburg-Shmuel T, Fischer B and Reiser G. (2014) 5-OMe-uridine-5'-O-( $\alpha$ boranodiphosphate), a novel nucleotide derivative highly active at the human P2Y(6) receptor protects against death-receptor mediated glial apoptosis. Neurosci Lett 578: 80-4 [PMID:24970757]

158. Hamel M, Henault M, Hyjazie H, Morin N, Bayly C, Skorey K, Therien AG, Mancini J, Brideau C and Kargman S. (2011) Discovery of novel P2Y14 agonist and antagonist using conventional and nonconventional methods. J Biomol Screen 16: 1098-105 [PMID:21821827]

159. Harper S, Webb TE, Charlton SJ, Ng LL and Boarder MR. (1998) Evidence that P2Y4 nucleotide receptors are involved in the regulation of rat aortic smooth muscle cells by UTP and ATP. $\mathrm{BrJ}$ Pharmacol 124: 703-10 [PMID:9690862]

160. Hasegawa M, Sugidachi A, Ogawa T, Isobe T, Jakubowski JA and Asai F. (2005) Stereoselective inhibition of human platelet aggregation by R-138727, the active metabolite of CS-747 (prasugrel, LY640315), a novel P2Y12 receptor inhibitor. Thromb Haemost 94: 593-8 [PMID:16268477]

161. Haynes SE, Hollopeter G, Yang G, Kurpius D, Dailey ME, Gan WB and Julius D. (2006) The P2Y12 receptor regulates microglial activation by extracellular nucleotides. Nat Neurosci 9: 1512-9 [PMID:17115040]

162. Hebert TE, Moffett S, Morello JP, Loisel TP, Bichet DG, Barret C and Bouvier M. (1996) A peptide derived from a beta2-adrenergic receptor transmembrane domain inhibits both receptor dimerization and activation. J Biol Chem 271: 16384-92 [PMID:8663163]

163. Hechler B, Eckly A, Ohlmann P, Cazenave J-P and Gachet C. (1998) The P2Y 1 receptor, necessary but not sufficient to support full ADP-induced platelet aggregation, is not the target of the drug clopidogrel. Br J Haematol 103: 858-866 [PMID:9858246]

164. Hechler B, Freund M, Ravanat C, Magnenat S, Cazenave JP and Gachet C. (2008) Reduced atherosclerotic lesions in P2Y1/apolipoprotein E double-knockout mice: the contribution of nonhematopoietic-derived P2Y1 receptors. Circulation 118: 754-63 [PMID:18663083]

165. Hechler B, Leon C, Vial C, Vigne P, Frelin C, Cazenave JP and Gachet C. (1998) The P2Y1 receptor is necessary for adenosine 5'-diphosphate-induced platelet aggregation. Blood 92: 152159 [PMID:9639511]

166. Hechler B, Vigne P, Léon C, Breittmayer JP, Gachet C and Frelin C. (1998) ATP derivatives are antagonists of the P2Y1 receptor: similarities to the platelet ADP receptor. Mol Pharmacol 53: 727-33 [PMID:9547364]

167. Heinrich A, Kittel A, Csölle C, Sylvester Vizi E and Sperlágh B. (2008) Modulation of neurotransmitter release by P2X and P2Y receptors in the rat spinal cord. Neuropharmacology 54: 375-86 [PMID:18063000]

168. Herbert JM and Savi P. (2003) P2Y12, a new platelet ADP receptor, target of clopidogrel. Semin 
Vasc Med 3: 113-22 [PMID:15199474]

169. Herzog H, Darby K, Hort YJ and Shine J. (1996) Intron 17 of the human retinoblastoma susceptibility gene encodes an actively transcribed G protein-coupled receptor gene. Genome Res 6: 858-61 [PMID:8889552]

170. Hetherington SL, Singh RK, Lodwick D, Thompson JR, Goodall AH and Samani NJ. (2005) Dimorphism in the P2Y1 ADP receptor gene is associated with increased platelet activation response to ADP. Arterioscler Thromb Vasc Biol 25: 252-7 [PMID:15514209]

171. Hillmann P, Ko GY, Spinrath A, Raulf A, von Kügelgen I, Wolff SC, Nicholas RA, Kostenis E, Höltje HD and Müller CE. (2009) Key determinants of nucleotide-activated G protein-coupled P2Y(2) receptor function revealed by chemical and pharmacological experiments, mutagenesis and homology modeling. J Med Chem 52: 2762-75 [PMID:19419204]

172. Hoffmann K, Baqi Y, Morena MS, Glänzel M, Müller CE and von Kügelgen I. (2009) Interaction of new, very potent non-nucleotide antagonists with Arg256 of the human platelet P2Y12 receptor. J Pharmacol Exp Ther 331: 648-55 [PMID:19690189]

173. Hoffmann K, Lutz DA, Straßburger J, Baqi Y, Müller CE and von Kügelgen I. (2014) Competitive mode and site of interaction of ticagrelor at the human platelet P2Y12 -receptor. $J$ Thromb Haemost 12: 1898-905 [PMID:25186974]

174. Hohenstein B, Renk S, Lang K, Daniel C, Freund M, Léon C, Amann KU, Gachet C and Hugo CP. (2007) P2Y1 gene deficiency protects from renal disease progression and capillary rarefaction during passive crescentic glomerulonephritis. J Am Soc Nephrol 18: 494-505 [PMID:17215444]

175. Hollopeter G, Jantzen HM, Vincent D, Li G, England L, Ramakrishnan V, Yang RB, Nurden P, Nurden A and Julius D et al.. (2001) Identification of the platelet ADP receptor targeted by antithrombotic drugs. Nature 409: 202-7 [PMID:11196645]

176. Homolya L, Watt WC, Lazarowski ER, Koller BH and Boucher RC. (1999) Nucleotide-regulated calcium signaling in lung fibroblasts and epithelial cells from normal and P2Y(2) receptor (-/-) mice. J Biol Chem 274: 26454-60 [PMID:10473605]

177. Horckmans M, Léon-Gómez E, Robaye B, Balligand JL, Boeynaems JM, Dessy C and Communi D. (2012) Gene deletion of P2Y4 receptor lowers exercise capacity and reduces myocardial hypertrophy with swimming exercise. Am J Physiol Heart Circ Physiol 303: H835-43 [PMID:22865387]

178. Horckmans M, Robaye B, Léon-Gómez E, Lantz N, Unger P, Dol-Gleizes F, Clouet S, Cammarata D, Schaeffer P and Savi P et al.. (2012) P2Y(4) nucleotide receptor: a novel actor in post-natal cardiac development. Angiogenesis 15: 349-60 [PMID:22437266]

179. Hou M, Harden TK, Kuhn CM, Baldetorp B, Lazarowski E, Pendergast W, Möller S, Edvinsson L and Erlinge D. (2002) UDP acts as a growth factor for vascular smooth muscle cells by activation of P2Y(6) receptors. Am J Physiol Heart Circ Physiol 282: H784-92 [PMID:11788430]

180. Houston D, Ohno M, Nicholas RA, Jacobson KA and Harden TK. (2006) [32P]2-iodo-N6-methyl(N)-methanocarba-2'-deoxyadenosine-3',5'-bisphosphate ([32P]MRS2500), a novel radioligand for quantification of native P2Y1 receptors. Br J Pharmacol 147: 459-67 [PMID:16299552]

181. Humphries RG. (2000) Pharmacology of AR-C69931MX and related compounds: from pharmacological tools to clinical trials. Haematologica 85: 66-72

182. Humphries RG, Tomlinson W, Clegg JA, Ingall AH, Kindon ND and Leff P. (1995) Pharmacological profile of the novel P2T-purinoceptor antagonist, FPL 67085 in vitro and in the anaesthetized rat in vivo. Br J Pharmacol 115: 1110-6 [PMID:7582510]

183. Humphries RG, Tomlinson W, Ingall AH, Cage PA and Leff P. (1994) FPL 66096: a novel, highly potent and selective antagonist at human platelet P2T-purinoceptors. Br J Pharmacol 113: 105763 [PMID:7858849]

184. Hur DG, Lee JH, Oh SH, Kim YH, Lee JH, Shin DH, Chang SO and Kim CS. (2007) KCNQ1/KCNE1 K+ channel and P2Y4 receptor are co-expressed from the time of birth in the apical membrane of rat strial marginal cells. Acta Otolaryngol Suppl: 30-5 [PMID:17882567]

185. Ingall AH, Dixon J, Bailey A, Coombs ME, Cox D, McInally JI, Hunt SF, Kindon ND, Teobald BJ and Willis PA et al.. (1999) Antagonists of the platelet P2T receptor: a novel approach to antithrombotic therapy. J Med Chem 42: 213-20 [PMID:9925726]

186. Inoue K, Hosoi J and Denda M. (2007) Extracellular ATP has stimulatory effects on the expression and release of IL-6 via purinergic receptors in normal human epidermal keratinocytes. J Invest Dermatol 127: 362-71 [PMID:16946718]

187. Ito M, Egashira SI, Yoshida K, Mineno T, Kumagai K, Kojima H, Okabe T, Nagano T, Ui M and Matsuoka I. (2017) Identification of novel selective $\mathrm{P}_{2} \mathrm{Y}_{6}$ receptor antagonists by highthroughput screening assay. Life Sci 180: 137-142 [PMID:28527783]

188. Ivanov AA, Fricks I, Kendall Harden T and Jacobson KA. (2007) Molecular dynamics simulation of the P2Y14 receptor. Ligand docking and identification of a putative binding site of the distal hexose moiety. Bioorg Med Chem Lett 17: 761-766 [PMID:17088057]

189. Ivanov AA, Ko H, Cosyn L, Maddileti S, Besada P, Fricks I, Costanzi S, Harden TK, Calenbergh SV and Jacobson KA. (2007) Molecular modeling of the human P2Y2 receptor and design of a selective agonist, 2'-amino-2'-deoxy-2-thiouridine 5'-triphosphate. J Med Chem 50: 1166-76 
[PMID:17302398]

190. Jacobson KA. (2013) Structure-based approaches to ligands for G-protein-coupled adenosine and P2Y receptors, from small molecules to nanoconjugates. J Med Chem 56: 3749-67 [PMID:23597047]

191. Jacobson KA, Deflorian F, Mishra S and Costanzi S. (2011) Pharmacochemistry of the platelet purinergic receptors. Purinergic Signal 7: 305-24 [PMID:21484092]

192. Jacobson KA, Delicado EG, Gachet C, Kennedy C, von Kügelgen I, Li B, Miras-Portugal MT, Novak I, Schöneberg T and Perez-Sen R et al.. (2020) Update of P2Y receptor pharmacology: IUPHAR Review 27. Br J Pharmacol 177: 2413-2433 [PMID:32037507]

193. Jacobson KA, Hoffmann C, Kim YC, Camaioni E, Nandanan E, Jang SY, Guo DP, Ji XD, von Kügelgen I and Moro S et al.. (1999) Molecular recognition in P2 receptors: ligand development aided by molecular modeling and mutagenesis. Prog Brain Res 120: 119-32 [PMID:10550992]

194. Jacobson KA, Ivanov AA, de Castro S, Harden TK and Ko H. (2009) Development of selective agonists and antagonists of P2Y receptors. Purinergic Signal 5: 75-89 [PMID:18600475]

195. Jacobson KA, Jarvis MF and Williams M. (2002) Purine and pyrimidine (P2) receptors as drug targets. J Med Chem 45: 4057-93 [PMID:12213051]

196. Jacquet S, Malaval C, Martinez LO, Sak K, Rolland C, Perez C, Nauze M, Champagne E, Tercé F and Gachet $\mathrm{C}$ et al.. (2005) The nucleotide receptor P2Y13 is a key regulator of hepatic highdensity lipoprotein (HDL) endocytosis. Cell Mol Life Sci 62: 2508-15 [PMID:16231090]

197. Janssens R, Boeynaems JM, Godart M and Communi D. (1997) Cloning of a human heptahelical receptor closely related to the P2Y5 receptor. Biochem Biophys Res Commun 236: 106-12 [PMID:9223435]

198. Janssens R, Communi D, Pirotton S, Samson M, Parmentier M and Boeynaems JM. (1996) Cloning and tissue distribution of the human P2Y1 receptor. Biochem Biophys Res Commun 221: 588-93 [PMID:8630005]

199. Janssens R, Paindavoine P, Parmentier M and Boeynaems JM. (1999) Human P2Y2 receptor polymorphism: identification and pharmacological characterization of two allelic variants. $\mathrm{Br} J$ Pharmacol 127: 709-16 [PMID:10401562]

200. Jayasekara PS, Barrett MO, Ball CB, Brown KA, Hammes E, Balasubramanian R, Harden TK and Jacobson KA. (2014) 4-Alkyloxyimino derivatives of uridine-5'-triphosphate: distal modification of potent agonists as a strategy for molecular probes of P2Y2, P2Y4, and P2Y6 receptors. J Med Chem 57: 3874-83 [PMID:24712832]

201. Jiang Q, Guo D, Lee BX, Van Rhee AM, Kim YC, Nicholas RA, Schachter JB, Harden TK and Jacobson KA. (1997) A mutational analysis of residues essential for ligand recognition at the human P2Y1 receptor. Mol Pharmacol 52: 499-507 [PMID:9281613]

202. Jiménez E, Zafra F, Pérez-Sen R, Delicado EG, Miras-Portugal MT, Aragón C and LópezCorcuera B. (2011) P2Y purinergic regulation of the glycine neurotransmitter transporters. $J$ Biol Chem 286: 10712-24 [PMID:21245148]

203. Jin J, Daniel JL and Kunapuli SP. (1998) Molecular basis for ADP-induced platelet activation. II. The P2Y1 receptor mediates ADP-induced intracellular calcium mobilization and shape change in platelets. J Biol Chem 273: 2030-4 [PMID:9442040]

204. Jordan BA and Devi LA. (1999) G-protein-coupled receptor heterodimerization modulates receptor function. Nature 399: 697-700 [PMID:10385123]

205. Kahner BN, Dorsam RT and Kunapuli SP. (2008) Role of P2Y receptor subtypes in plateletderived microparticle generation. Front Biosci 13: 433-9 [PMID:17981558]

206. Kauffenstein G, Hechler B, Cazenave JP and Gachet C. (2004) Adenine triphosphate nucleotides are antagonists at the P2Y receptor. J Thromb Haemost 2: 1980-8 [PMID:15550030]

207. Kemp PA, Sugar RA and Jackson AD. (2004) Nucleotide-mediated mucin secretion from differentiated human bronchial epithelial cells. Am J Respir Cell Mol Biol 31: 446-55 [PMID:15231488]

208. Kennedy C, Chootip K, Mitchell C, Syed NI and Tengah A. (2013) P2X and P2Y nucleotide receptors as targets in cardiovascular disease. Future Med Chem 5: 431-49 [PMID:23495690]

209. Kennedy C, Herold CL, Qi A, Nicholas RA and Harden TK. (1999) Differing pharmacological properties of the human and rat $\mathrm{P}_{2} \mathrm{Y}_{4}$ receptors. Br J Pharmacol 126: $21 \mathrm{P}$

210. Kennedy C, Qi AD, Herold CL, Harden TK and Nicholas RA. (2000) ATP, an agonist at the rat P2Y(4) receptor, is an antagonist at the human P2Y(4) receptor. Mol Pharmacol 57: 926-31 [PMID:10779375]

211. Khan A, Li D, Ibrahim S, Smyth E and Woulfe DS. (2014) The physical association of the P2Y12 receptor with PAR4 regulates arrestin-mediated Akt activation. Mol Pharmacol 86: 1-11 [PMID:24723492]

212. Kim B, Jeong HK, Kim JH, Lee SY, Jou I and Joe EH. (2011) Uridine 5'-diphosphate induces chemokine expression in microglia and astrocytes through activation of the P2Y6 receptor. $J$ Immunol 186: 3701-9 [PMID:21317391]

213. Kim HJ, Ajit D, Peterson TS, Wang Y, Camden JM, Gibson Wood W, Sun GY, Erb L, Petris M and Weisman GA. (2012) Nucleotides released from $A \beta_{1-42}$-treated microglial cells increase cell 
migration and $A \beta_{1-42}$ uptake through $\mathrm{P}_{2} \mathrm{Y}_{2}$ receptor activation. J Neurochem 121: 228-38 [PMID:22353164]

214. Kim HS, Ohno M, Xu B, Kim HO, Choi Y, Ji XD, Maddileti S, Marquez VE, Harden TK and Jacobson KA. (2003) 2-Substitution of adenine nucleotide analogues containing a bicyclo[3.1.0]hexane ring system locked in a northern conformation: enhanced potency as P2Y1 receptor antagonists. J Med Chem 46: 4974-87 [PMID:14584948]

215. Kim HS, Ravi RG, Marquez VE, Maddileti S, Wihlborg AK, Erlinge D, Malmsjö M, Boyer JL, Harden TK and Jacobson KA. (2002) Methanocarba modification of uracil and adenine nucleotides: high potency of Northern ring conformation at P2Y1, P2Y2, P2Y4, and P2Y11 but not P2Y6 receptors. J Med Chem 45: 208-18 [PMID:11754592]

216. Kim YC, Lee JS, Sak K, Marteau F, Mamedova L, Boeynaems JM and Jacobson KA. (2005) Synthesis of pyridoxal phosphate derivatives with antagonist activity at the P2Y13 receptor. Biochem Pharmacol 70: 266-74 [PMID:15913566]

217. King BF, Townsend-Nicholson A and Burnstock G. (1998) Metabotropic receptors for ATP and UTP: exploring the correspondence between native and recombinant nucleotide receptors. Trends Pharmacol Sci 19: 506-514 [PMID:9871413]

218. Kiselev E, Balasubramanian R, Uliassi E, Brown KA, Trujillo K, Katritch V, Hammes E, Stevens RC, Harden TK and Jacobson KA. (2015) Design, synthesis, pharmacological characterization of a fluorescent agonist of the $\mathrm{P}_{2 \mathrm{Y}_{14}}$ receptor. Bioorg Med Chem Lett 25: 4733-9 [PMID:26303895]

219. Kiselev E, Barrett MO, Katritch V, Paoletta S, Weitzer CD, Brown KA, Hammes E, Yin AL, Zhao $\mathrm{Q}$ and Stevens RC et al.. (2014) Exploring a 2-naphthoic acid template for the structure-based design of P2Y14 receptor antagonist molecular probes. ACS Chem Biol 9: 2833-42 [PMID:25299434]

220. Kishore BK, Krane CM, Miller RL, Shi H, Zhang P, Hemmert A, Sun R and Nelson RD. (2005) $\mathrm{P} 2 \mathrm{Y} 2$ receptor $\mathrm{mRNA}$ and protein expression is altered in inner medullas of hydrated and dehydrated rats: relevance to AVP-independent regulation of IMCD function. Am J Physiol Renal Physiol 288: F1164-72 [PMID:15687250]

221. Ko H, Carter RL, Cosyn L, Petrelli R, de Castro S, Besada P, Zhou Y, Cappellacci L, Franchetti P and Grifantini M et al.. (2008) Synthesis and potency of novel uracil nucleotides and derivatives as P2Y2 and P2Y6 receptor agonists. Bioorg Med Chem 16: 6319-32 [PMID:18514530]

222. Ko H, Fricks I, Ivanov AA, Harden TK and Jacobson KA. (2007) Structure-activity relationship of uridine 5'-diphosphoglucose analogues as agonists of the human P2Y14 receptor. J Med Chem 50: 2030-9 [PMID:17407275]

223. Kobayashi D, Ohkubo S and Nakahata N. (2006) Contribution of extracellular signal-regulated kinase to UTP-induced interleukin-6 biosynthesis in HaCaT keratinocytes. J Pharmacol Sci 102: 368-76 [PMID:17130674]

224. Kobayashi K, Fukuoka T, Yamanaka H, Iyamanaka H, Dai Y, Obata K, Tokunaga A and Noguchi K. (2006) Neurons and glial cells differentially express P2Y receptor mRNAs in the rat dorsal root ganglion and spinal cord. J Comp Neurol 498: 443-54 [PMID:16874807]

225. Kobayashi K, Yamanaka H, Fukuoka T, Dai Y, Obata K and Noguchi K. (2008) P2Y12 receptor upregulation in activated microglia is a gateway of p38 signaling and neuropathic pain. $J$ Neurosci 28: 2892-902 [PMID:18337420]

226. Kobayashi K, Yamanaka H, Yanamoto F, Okubo M and Noguchi K. (2012) Multiple P2Y subtypes in spinal microglia are involved in neuropathic pain after peripheral nerve injury. Glia 60: 152939 [PMID:22736439]

227. Kobayashi T, Soma T, Noguchi T, Nakagome K, Nakamoto H, Kita H and Nagata M. (2015) ATP drives eosinophil effector responses through P2 purinergic receptors. Allergol Int 64 Suppl: S30-6 [PMID:26344078]

228. Koizumi S, Shigemoto-Mogami Y, Nasu-Tada K, Shinozaki Y, Ohsawa K, Tsuda M, Joshi BV, Jacobson KA, Kohsaka S and Inoue K. (2007) UDP acting at P2Y6 receptors is a mediator of microglial phagocytosis. Nature 446: 1091-5 [PMID:17410128]

229. Kong D, Xue T, Guo B, Cheng J, Liu S, Wei J, Lu Z, Liu H, Gong G and Lan T et al.. (2019) Optimization of P2Y 12 Antagonist Ethyl 6-(4-((Benzylsulfonyl)carbamoyl)piperidin-1-yl)-5-cyano2-methylnicotinate (AZD1283) Led to the Discovery of an Oral Antiplatelet Agent with Improved Druglike Properties. J Med Chem 62: 3088-3106 [PMID:30843696]

230. Kong Q, Peterson TS, Baker O, Stanley E, Camden J, Seye CI, Erb L, Simonyi A, Wood WG and Sun GY et al.. (2009) Interleukin-1beta enhances nucleotide-induced and alpha-secretasedependent amyloid precursor protein processing in rat primary cortical neurons via upregulation of the P2Y(2) receptor. J Neurochem 109: 1300-10 [PMID:19317852]

231. Korcok J, Raimundo LN, Du X, Sims SM and Dixon SJ. (2005) P2Y6 nucleotide receptors activate NF-kappaB and increase survival of osteoclasts. J Biol Chem 280: 16909-15 [PMID:15722352]

232. Kornum BR, Kawashima M, Faraco J, Lin L, Rico TJ, Hesselson S, Axtell RC, Kuipers H, Weiner $\mathrm{K}$ and Hamacher A et al.. (2011) Common variants in P2RY11 are associated with narcolepsy. Nat Genet 43: 66-71 [PMID:21170044]

233. Koshiba M, Apasov S, Sverdlov V, Chen P, Erb L, Turner JT, Weisman GA and Sitkovsky MV. 
(1997) Transient up-regulation of P2Y2 nucleotide receptor mRNA expression is an immediate early gene response in activated thymocytes. Proc Natl Acad Sci USA 94: 831-6 [PMID:9023342]

234. Kotevic I, Kirschner KM, Porzig H and Baltensperger K. (2005) Constitutive interaction of the P2Y2 receptor with the hematopoietic cell-specific G protein G(alpha16) and evidence for receptor oligomers. Cell Signal 17: 869-80 [PMID:15763429]

235. Krzeminski P, Misiewicz I, Pomorski P, Kasprzycka-Guttman T, Barańska J and Brańska J. (2007) Mitochondrial localization of P2Y1, P2Y2 and P2Y12 receptors in rat astrocytes and glioma C6 cells. Brain Res Bull 71: 587-92 [PMID:17292801]

236. Krzemiński P, Pomorski P and Barańska J. (2008) The P2Y14 receptor activity in glioma C6 cells. Eur J Pharmacol 594: 49-54 [PMID:18638471]

237. Kudirka JC, Panupinthu N, Tesseyman MA, Dixon SJ and Bernier SM. (2007) P2Y nucleotide receptor signaling through MAPK/ERK is regulated by extracellular matrix: involvement of beta3 integrins. J Cell Physiol 213: 54-64 [PMID:17620283]

238. Kunapuli SP. (1998) Functional characterization of platelet ADP receptors. Platelets 9: 343-51 [PMID:16793717]

239. Kunzelmann K, Bachhuber T, Regeer R, Markovich D, Sun J and Schreiber R. (2005) Purinergic inhibition of the epithelial $\mathrm{Na}+$ transport via hydrolysis of PIP2. FASEB J 19: 142-3 [PMID:15504951]

240. Köttgen M, Löffler T, Jacobi C, Nitschke R, Pavenstädt H, Schreiber R, Frische S, Nielsen S and Leipziger J. (2003) P2Y6 receptor mediates colonic $\mathrm{NaCl}$ secretion via differential activation of cAMP-mediated transport. J Clin Invest 111: 371-9 [PMID:12569163]

241. Lau OC, Samarawickrama C and Skalicky SE. (2014) P2Y2 receptor agonists for the treatment of dry eye disease: a review. Clin Ophthalmol 8: 327-34 [PMID:24511227]

242. Lazarowski ER, Rochelle LG, O'Neal WK, Ribeiro CM, Grubb BR, Zhang V, Harden TK and Boucher RC. (2001) Cloning and functional characterization of two murine uridine nucleotide receptors reveal a potential target for correcting ion transport deficiency in cystic fibrosis gallbladder. J Pharmacol Exp Ther 297: 43-9 [PMID:11259526]

243. Lazarowski ER, Watt WC, Stutts MJ, Boucher RC and Harden TK. (1995) Pharmacological selectivity of the cloned human P2U-purinoceptor: potent activation by diadenosine tetraphosphate. Br J Pharmacol 116: 1619-27 [PMID:8564228]

244. Lazarowski ER, Watt WC, Stutts MJ, Brown HA, Boucher RC and Harden TK. (1996) Enzymatic synthesis of UTP gamma S, a potent hydrolysis resistant agonist of P2U-purinoceptors. $\mathrm{BrJ}$ Pharmacol 117: 203-9 [PMID:8825364]

245. Lee BC, Cheng T, Adams GB, Attar EC, Miura N, Lee SB, Saito Y, Olszak I, Dombkowski D and Olson DP et al.. (2003) P2Y-like receptor, GPR105 (P2Y14), identifies and mediates chemotaxis of bone-marrow hematopoietic stem cells. Genes Dev 17: 1592-604 [PMID:12842911]

246. Lee JH, Heo JH, Chang SO, Kim CS and Oh SH. (2006) Reactive blue 2, an antagonist of rat $\mathrm{P} 2 \mathrm{Y} 4$, increases $\mathrm{K}+$ secretion in rat cochlea strial marginal cells. Hear Res 219: 66-73 [PMID:16839719]

247. Lemon G, Brockhausen J, Li GH, Gibson WG and Bennett MR. (2005) Calcium mobilization and spontaneous transient outward current characteristics upon agonist activation of P2Y2 receptors in smooth muscle cells. Biophys J 88: 1507-23 [PMID:15556987]

248. Li Q, Chen BL, Ozdemir V, Ji W, Mao YM, Wang LC, Lei HP, Fan L, Zhang W and Liu J et al.. (2007) Frequency of genetic polymorphisms of COX1, GPIIIa and P2Y1 in a Chinese population and association with attenuated response to aspirin. Pharmacogenomics 8: 577-86 [PMID:17559347]

249. Li Q, Olesky M, Palmer RK, Harden TK and Nicholas RA. (1998) Evidence that the p2y3 receptor is the avian homologue of the mammalian P2Y6 receptor. Mol Pharmacol 54: 541-6 [PMID:9730913]

250. Li Q, Schachter JB, Harden TK and Nicholas RA. (1997) The 6H1 orphan receptor, claimed to be the p2y5 receptor, does not mediate nucleotide-promoted second messenger responses. Biochem Biophys Res Commun 236: 455-60 [PMID:9240460]

251. Liao Z, Seye CI, Weisman GA and Erb L. (2007) The P2Y2 nucleotide receptor requires interaction with alpha v integrins to access and activate G12. J Cell Sci 120: 1654-62 [PMID:17452627]

252. Liu J, Liao Z, Camden J, Griffin KD, Garrad RC, Santiago-Pérez LI, González FA, Seye CI, Weisman GA and Erb L. (2004) Src homology 3 binding sites in the P2Y2 nucleotide receptor interact with Src and regulate activities of Src, proline-rich tyrosine kinase 2, and growth factor receptors. J Biol Chem 279: 8212-8 [PMID:14670955]

253. Liu X, Hashimoto-Torii K, Torii M, Haydar TF and Rakic P. (2008) The role of ATP signaling in the migration of intermediate neuronal progenitors to the neocortical subventricular zone. Proc Natl Acad Sci USA 105: 11802-7 [PMID:18689674]

254. Lustig KD, Shiau AK, Brake AJ and Julius D. (1993) Expression cloning of an ATP receptor from mouse neuroblastoma cells. Proc Natl Acad Sci USA 90: 5113-7 [PMID:7685114] 
255. Léon C, Hechler B, Freund M, Eckly A, Vial C, Ohlmann P, Dierich A, LeMeur M, Cazenave JP and Gachet C. (1999) Defective platelet aggregation and increased resistance to thrombosis in purinergic P2Y(1) receptor-null mice. J Clin Invest 104: 1731-7 [PMID:10606627]

256. Léon C, Hechler B, Vial C, Leray C, Cazenave JP and Gachet C. (1997) The P2Y1 receptor is an ADP receptor antagonized by ATP and expressed in platelets and megakaryoblastic cells. FEBS Lett 403: 26-30 [PMID:9038354]

257. Magnone M, Basile G, Bruzzese D, Guida L, Signorello MG, Chothi MP, Bruzzone S, Millo E, Qi $\mathrm{AD}$ and Nicholas RA et al.. (2008) Adenylic dinucleotides produced by CD38 are negative endogenous modulators of platelet aggregation. J Biol Chem 283: 24460-8 [PMID:18606819]

258. Maier R, Glatz A, Mosbacher J and Bilbe G. (1997) Cloning of P2Y6 cDNAs and identification of a pseudogene: comparison of $\mathrm{P} 2 \mathrm{Y}$ receptor subtype expression in bone and brain tissues. Biochem Biophys Res Commun 240: 298-302 [PMID:9412455]

259. Malaval C, Laffargue M, Barbaras R, Rolland C, Peres C, Champagne E, Perret B, Tercé F, Collet X and Martinez LO. (2009) RhoA/ROCK I signalling downstream of the P2Y13 ADPreceptor controls HDL endocytosis in human hepatocytes. Cell Signal 21: 120-7 [PMID:18948190]

260. Malin SA, Davis BM, Koerber HR, Reynolds IJ, Albers KM and Molliver DC. (2008) Thermal nociception and TRPV1 function are attenuated in mice lacking the nucleotide receptor P2Y2. Pain 138: 484-96 [PMID:18343036]

261. Malin SA and Molliver DC. (2010) Gi- and Gq-coupled ADP (P2Y) receptors act in opposition to modulate nociceptive signaling and inflammatory pain behavior. Mol Pain 6: 21 [PMID:20398327]

262. Malmsjö M, Hou M, Pendergast W, Erlinge D and Edvinsson L. (2003) Potent P2Y6 receptor mediated contractions in human cerebral arteries. BMC Pharmacol 3: 4 [PMID:12737633]

263. Mamedova L, Capra V, Accomazzo MR, Gao ZG, Ferrario S, Fumagalli M, Abbracchio MP, Rovati GE and Jacobson KA. (2005) CysLT1 leukotriene receptor antagonists inhibit the effects of nucleotides acting at P2Y receptors. Biochem Pharmacol 71: 115-25 [PMID:16280122]

264. Mamedova LK, Joshi BV, Gao ZG, von Kügelgen I and Jacobson KA. (2004) Diisothiocyanate derivatives as potent, insurmountable antagonists of P2Y6 nucleotide receptors. Biochem Pharmacol 67: 1763-70 [PMID:15081875]

265. Mamedova LK, Wang R, Besada P, Liang BT and Jacobson KA. (2008) Attenuation of apoptosis in vitro and ischemia/reperfusion injury in vivo in mouse skeletal muscle by P2Y6 receptor activation. Pharmacol Res 58: 232-9 [PMID:18805489]

266. Mao C, Wang S, Xiao Y, Xu J, Jiang Q, Jin M, Jiang X, Guo H, Ning G and Zhang Y. (2011) Impairment of regulatory capacity of CD4+CD25+ regulatory T cells mediated by dendritic cell polarization and hyperthyroidism in Graves' disease. J Immunol 186: 4734-43 [PMID:21398613]

267. Marcet B, Chappe V, Delmas P and Verrier B. (2004) Pharmacological and signaling properties of endogenous $\mathrm{P} 2 \mathrm{Y} 1$ receptors in cystic fibrosis transmembrane conductance regulatorexpressing Chinese hamster ovary cells. J Pharmacol Exp Ther 309: 533-539 [PMID:14742736]

268. Marchese A, George SR, Kolakowski Jr LF, Lynch KR and O'Dowd BF. (1999) Novel GPCRs and their endogenous ligands: expanding the boundaries of physiology and pharmacology. Trends Pharmacol Sci 20: 370-5 [PMID:10462760]

269. Marcus DC, Liu J, Lee JH, Scherer EQ, Scofield MA and Wangemann P. (2005) Apical membrane P2Y4 purinergic receptor controls $\mathrm{K}+$ secretion by strial marginal cell epithelium. Cell Commun Signal 3: 13 [PMID:16266433]

270. Marteau F, Gonzalez NS, Communi D, Goldman M, Boeynaems JM and Communi D. (2005) Thrombospondin-1 and indoleamine 2,3-dioxygenase are major targets of extracellular ATP in human dendritic cells. Blood 106: 3860-6 [PMID:16118322]

271. Marteau F, Le Poul E, Communi D, Communi D, Labouret C, Savi P, Boeynaems JM and Gonzalez NS. (2003) Pharmacological characterization of the human P2Y13 receptor. Mol Pharmacol 64: 104-12 [PMID:12815166]

272. Maruoka H, Barrett MO, Ko H, Tosh DK, Melman A, Burianek LE, Balasubramanian R, Berk B, Costanzi S and Harden TK et al.. (2010) Pyrimidine ribonucleotides with enhanced selectivity as P2Y(6) receptor agonists: novel 4-alkyloxyimino, (S)-methanocarba, and 5'-triphosphate gammaester modifications. J Med Chem 53: 4488-501 [PMID:20446735]

273. Maruoka H, Jayasekara MP, Barrett MO, Franklin DA, de Castro S, Kim N, Costanzi S, Harden TK and Jacobson KA. (2011) Pyrimidine nucleotides with 4-alkyloxyimino and terminal tetraphosphate $\delta$-ester modifications as selective agonists of the P2Y(4) receptor. J Med Chem 54: 4018-33 [PMID:21528910]

274. Masyuk AI, Gradilone SA, Banales JM, Huang BQ, Masyuk TV, Lee SO, Splinter PL, Stroope AJ and Larusso NF. (2008) Cholangiocyte primary cilia are chemosensory organelles that detect biliary nucleotides via P2Y12 purinergic receptors. Am J Physiol Gastrointest Liver Physiol 295: G725-34 [PMID:18687752]

275. Matos JE, Robaye B, Boeynaems JM, Beauwens R and Leipziger J. (2005) K+ secretion activated by luminal P2Y2 and P2Y4 receptors in mouse colon. J Physiol (Lond.) 564: 269-79 
[PMID:15718265]

276. Maueröder C, Kienhöfer D, Hahn J, Schauer C, Manger B, Schett G, Herrmann M and Hoffmann MH. (2015) How neutrophil extracellular traps orchestrate the local immune response in gout. $J$ Mol Med 93: 727-34 [PMID:26002146]

277. Meis S, Hamacher A, Hongwiset D, Marzian C, Wiese M, Eckstein N, Royer HD, Communi D, Boeynaems JM and Hausmann R et al.. (2010) NF546 [4,4'-(carbonylbis(imino-3,1-phenylenecarbonylimino-3,1-(4-methyl-phenylene)-carbonylimino))-bis(1,3-xylene-alpha,alpha'-

diphosphonic acid) tetrasodium salt] is a non-nucleotide P2Y11 agonist and stimulates release of interleukin-8 from human monocyte-derived dendritic cells. J Pharmacol Exp Ther 332: 238-47 [PMID:19815812]

278. Meyer MP, Clarke JD, Patel K, Townsend-Nicholson A and Burnstock G. (1999) Selective expression of purinoceptor $\mathrm{CP} 2 \mathrm{Y} 1$ suggests a role for nucleotide signalling in development of the chick embryo. Dev Dyn 214: 152-8 [PMID:10030594]

279. Michelson AD. (2008) P2Y12 antagonism: promises and challenges. Arterioscler Thromb Vasc Biol 28: s33-s38 [PMID:18174449]

280. Milosevic J, Brandt A, Roemuss U, Arnold A, Wegner F, Schwarz SC, Storch A, Zimmermann H and Schwarz J. (2006) Uracil nucleotides stimulate human neural precursor cell proliferation and dopaminergic differentiation: involvement of MEK/ERK signalling. J Neurochem 99: 913923 [PMID:17076658]

281. Moore DJ, Chambers JK, Wahlin JP, Tan KB, Moore GB, Jenkins O, Emson PC and Murdock PR. (2001) Expression pattern of human P2Y receptor subtypes: a quantitative reverse transcriptionpolymerase chain reaction study. Biochim Biophys Acta 1521: 107-19 [PMID:11690642]

282. Moore DJ, Murdock PR, Watson JM, Faull RL, Waldvogel HJ, Szekeres PG, Wilson S, Freeman KB and Emson PC. (2003) GPR105, a novel Gi/o-coupled UDP-glucose receptor expressed on brain glia and peripheral immune cells, is regulated by immunologic challenge: possible role in neuroimmune function. Brain Res Mol Brain Res 118: 10-23 [PMID:14559350]

283. Morales-Ramos AI, Mecom JS, Kiesow TJ, Graybill TL, Brown GD, Aiyar NV, Davenport EA, Kallal LA, Knapp-Reed BA and Li P et al.. (2008) Tetrahydro-4-quinolinamines identified as novel P2Y(1) receptor antagonists. Bioorg Med Chem Lett 18: 6222-6 [PMID:18926700]

284. Moreschi I, Bruzzone S, Bodrato N, Usai C, Guida L, Nicholas RA, Kassack MU, Zocchi E and De Flora A. (2008) NAADP+ is an agonist of the human P2Y11 purinergic receptor. Cell Calcium 43: 344-55 [PMID:17707504]

285. Moreschi I, Bruzzone S, Nicholas RA, Fruscione F, Sturla L, Benvenuto F, Usai C, Meis S, Kassack MU and Zocchi E et al.. (2006) Extracellular NAD+ is an agonist of the human P2Y11 purinergic receptor in human granulocytes. J Biol Chem 281: 31419-29 [PMID:16926152]

286. Mori T, Miyashita T, Akiyama K, Inamoto R and Mori N. (2009) The expression of P2Y1, 2, 4, and 6 receptors in rat endolymphatic sac epithelia. Neuroreport 20: 419-23 [PMID:19223794]

287. Morrow GB, Nicholas RA and Kennedy C. (2014) UTP is not a biased agonist at human P2Y(11) receptors. Purinergic Signal 10: 581-5 [PMID:25015314]

288. Mufti F, Jung YH, Giancotti LA, Yu J, Chen Z, Phung NB, Jacobson KA and Salvemini D. (2020) $\mathrm{P} \mathrm{Y}_{14}$ Receptor Antagonists Reverse Chronic Neuropathic Pain in a Mouse Model. ACS Med Chem Lett 11: 1281-1286 [PMID:32551012]

289. Müller T, Bayer H, Myrtek D, Ferrari D, Sorichter S, Ziegenhagen MW, Zissel G, Virchow Jr JC, Luttmann W and Norgauer J et al.. (2005) The P2Y14 receptor of airway epithelial cells: coupling to intracellular Ca2+ and IL-8 secretion. Am J Respir Cell Mol Biol 33: 601-9 [PMID:16109883]

290. Nahum V, Tulapurkar M, Lévesque SA, Sévigny J, Reiser G and Fischer B. (2006) Diadenosine and diuridine poly(borano)phosphate analogues: synthesis, chemical and enzymatic stability, and activity at P2Y1 and P2Y2 receptors. J Med Chem 49: 1980-90 [PMID:16539385]

291. Nandanan E, Camaioni E, Jang SY, Kim YC, Cristalli G, Herdewijn P, Secrist 3rd JA, Tiwari KN, Mohanram A and Harden TK et al.. (1999) Structure-activity relationships of bisphosphate nucleotide derivatives as P2Y1 receptor antagonists and partial agonists. J Med Chem 42: 162538 [PMID:10229631]

292. Nandanan E, Jang SY, Moro S, Kim HO, Siddiqui MA, Russ P, Marquez VE, Busson R, Herdewijn $\mathrm{P}$ and Harden TK et al.. (2000) Synthesis, biological activity, and molecular modeling of ribosemodified deoxyadenosine bisphosphate analogues as P2Y(1) receptor ligands. J Med Chem 43: 829-42 [PMID:10715151]

293. Neary JT, Rathbone MP, Cattabeni F, Abbracchio MP and Burnstock G. (1996) Trophic actions of extracellular nucleotides and nucleosides on glial and neuronal cells. Trends Neurosci 19: 13-8 [PMID:8787135]

294. Nguyen T, Erb L, Weisman GA, Marchese A, Heng HH, Garrad RC, George SR, Turner JT and O'Dowd BF. (1995) Cloning, expression, and chromosomal localization of the human uridine nucleotide receptor gene. J Biol Chem 270: 30845-30848 [PMID:8537335]

295. Nicholas RA, Watt WC, Lazarowski ER, Li Q and Harden K. (1996) Uridine nucleotide selectivity of three phospholipase C-activating P2 receptors: identification of a UDP-selective, a UTP- 
selective, and an ATP- and UTP-specific receptor. Mol Pharmacol 50: 224-9 [PMID:8700127]

296. Nishida M, Sato Y, Uemura A, Narita Y, Tozaki-Saitoh H, Nakaya M, Ide T, Suzuki K, Inoue K and Nagao T et al.. (2008) P2Y6 receptor-Galpha12/13 signalling in cardiomyocytes triggers pressure overload-induced cardiac fibrosis. EMBO J 27: 3104-15 [PMID:19008857]

297. Nomura N, Miyajima N, Sazuka T, Tanaka A, Kawarabayasi Y, Sato S, Nagase T, Seki N, Ishikawa K and Tabata S. (1994) Prediction of the coding sequences of unidentified human genes. I. The coding sequences of 40 new genes (KIAA0001-KIAA0040) deduced by analysis of randomly sampled cDNA clones from human immature myeloid cell line KG-1. DNA Res 1: 27-35 [PMID:7584026]

298. Nonaka Y, Hiramoto T and Fujita N. (2005) Identification of endogenous surrogate ligands for human P2Y12 receptors by in silico and in vitro methods. Biochem Biophys Res Commun 337: 281-288 [PMID:16185654]

299. Noronha-Matos JB, Costa MA, Magalhães-Cardoso MT, Ferreirinha F, Pelletier J, Freitas R, Neves JM, Sévigny J and Correia-de-Sá P. (2012) Role of ecto-NTPDases on UDP-sensitive $\mathrm{P} 2 \mathrm{Y}(6)$ receptor activation during osteogenic differentiation of primary bone marrow stromal cells from postmenopausal women. J Cell Physiol 227: 2694-709 [PMID:21898410]

300. Ohlmann P, Lecchi A, El-Tayeb A, Müller CE, Cattaneo M and Gachet C. (2013) The platelet P2Y(12) receptor under normal and pathological conditions. Assessment with the radiolabeled selective antagonist [(3)H]PSB-0413. Purinergic Signal 9: 59-66 [PMID:22892887]

301. Ohsawa K, Irino Y, Nakamura Y, Akazawa C, Inoue K and Kohsaka S. (2007) Involvement of P2X4 and P2Y12 receptors in ATP-induced microglial chemotaxis. Glia 55: 604-16 [PMID:17299767]

302. Orriss I, Syberg S, Wang N, Robaye B, Gartland A, Jorgensen N, Arnett T and Boeynaems JM. (2011) Bone phenotypes of P2 receptor knockout mice. Front Biosci (Schol Ed) 3: 1038-46 [PMID:21622253]

303. Orriss IR, Burnstock G and Arnett TR. (2010) Purinergic signalling and bone remodelling. Curr Opin Pharmacol 10: 322-30 [PMID:20189453]

304. Orriss IR, Utting JC, Brandao-Burch A, Colston K, Grubb BR, Burnstock G and Arnett TR. (2007) Extracellular nucleotides block bone mineralization in vitro: evidence for dual inhibitory mechanisms involving both P2Y2 receptors and pyrophosphate. Endocrinology 148: 4208-16 [PMID:17569759]

305. Orriss IR, Wang N, Burnstock G, Arnett TR, Gartland A, Robaye B and Boeynaems JM. (2011) The P2Y(6) receptor stimulates bone resorption by osteoclasts. Endocrinology 152: 3706-16 [PMID:21828185]

306. Ortega F, Pérez-Sen R, Delicado EG and Teresa Miras-Portugal M. (2011) ERK1/2 activation is involved in the neuroprotective action of $\mathrm{P} 2 \mathrm{Y} 13$ and $\mathrm{P} 2 \mathrm{X} 7$ receptors against glutamate excitotoxicity in cerebellar granule neurons. Neuropharmacology 61: 1210-21 [PMID:21798274]

307. Palmer RK, Boyer JL, Schachter JB, Nicholas RA and Harden TK. (1998) Agonist action of adenosine triphosphates at the human P2Y1 receptor. Mol Pharmacol 54: 1118-23 [PMID:9855642]

308. Parandeh F, Abaraviciene SM, Amisten S, Erlinge D and Salehi A. (2008) Uridine diphosphate (UDP) stimulates insulin secretion by activation of P2Y6 receptors. Biochem Biophys Res Commun 370: 499-503 [PMID:18387359]

309. Park HS and Hourani SM. (1999) Differential effects of adenine nucleotide analogues on shape change and aggregation induced by adnosine 5-diphosphate (ADP) in human platelets. $\mathrm{Br} J$ Pharmacol 127: 1359-66 [PMID:10455285]

310. Park MK, Garrad RC, Weisman GA and Turner JT. (1997) Changes in P2Y1 nucleotide receptor activity during the development of rat salivary glands. Am J Physiol 272: C1388-93 [PMID:9142866]

311. Parr CE, Sullivan DM, Paradiso AM, Lazarowski ER, Burch LH, Olsen JC, Erb L, Weisman GA, Boucher RC and Turner JT. (1994) Cloning and expression of a human P2U nucleotide receptor, a target for cystic fibrosis pharmacotherapy. Proc Natl Acad Sci USA 91: 3275-9 [PMID:8159738]

312. Patel K, Barnes A, Camacho J, Paterson C, Boughtflower R, Cousens D and Marshall F. (2001) Activity of diadenosine polyphosphates at P2Y receptors stably expressed in $1321 \mathrm{~N} 1$ cells. Eur J Pharmacol 430: 203-10 [PMID:11711032]

313. Patel YM, Lordkipanidzé M, Lowe GC, Nisar SP, Garner K, Stockley J, Daly ME, Mitchell M, Watson SP and Austin SK et al.. (2014) A novel mutation in the P2Y12 receptor and a functionreducing polymorphism in protease-activated receptor 1 in a patient with chronic bleeding. $J$ Thromb Haemost 12: 716-25 [PMID:24612435]

314. Pausch MH, Lai M, Tseng E, Paulsen J, Bates B and Kwak S. (2004) Functional expression of human and mouse P2Y12 receptors in Saccharomyces cerevisiae. Biochem Biophys Res Commun 324: 171-7 [PMID:15464998]

315. Pelleg A, Schulman ES and Barnes PJ. (2016) Extracellular Adenosine 5'-Triphosphate in Obstructive Airway Diseases. Chest 150: 908-915 [PMID:27568579] 
316. Pendergast W, Yerxa BR, Douglass 3rd JG, Shaver SR, Dougherty RW, Redick CC, Sims IF and Rideout JL. (2001) Synthesis and P2Y receptor activity of a series of uridine dinucleoside 5'polyphosphates. Bioorg Med Chem Lett 11: 157-60 [PMID:11206448]

317. Pfefferkorn JA, Choi C, Winters T, Kennedy R, Chi L, Perrin LA, Lu G, Ping YW, McClanahan T and Schroeder R et al.. (2008) P2Y1 receptor antagonists as novel antithrombotic agents. Bioorg Med Chem Lett 18: 3338-43 [PMID:18445527]

318. Pintor J, Díaz-Rey MA and Miras-Portugal MT. (1993) Ap4A and ADP-beta-S binding to P2 purinoceptors present on rat brain synaptic terminals. Br J Pharmacol 108: 1094-9 [PMID:8485620]

319. Pintor J and Miras-Portugal MT. (2000) Receptors for diadenosine polyphosphates P2D, P2YApnA, P4 and dinucleotide receptors: are there too many? Trends Pharmacol Sci 21: 135 [PMID:10740288]

320. Pintor J and Miras-Portugal MT. (1995) P2 purinergic receptors for diadenosine polyphosphates in the nervous system. Gen Pharmacol 26: 229-35 [PMID:7590071]

321. Pochynyuk O, Bugaj V, Rieg T, Insel PA, Mironova E, Vallon V and Stockand JD. (2008) Paracrine regulation of the epithelial $\mathrm{Na}+$ channel in the mammalian collecting duct by purinergic P2Y2 receptor tone. J Biol Chem 283: 36599-607 [PMID:18981175]

322. Post JM, Alexander S, Wang YX, Vincelette J, Vergona R, Kent L, Bryant J, Sullivan ME, Dole WP and Morser J et al.. (2008) Novel P2Y12 adenosine diphosphate receptor antagonists for inhibition of platelet aggregation (II): pharmacodynamic and pharmacokinetic characterization. Thromb Res 122: 533-40 [PMID:18539312]

323. Price MJ. (2017) Cangrelor: Pharmacology, Clinical Data, and Role in Percutaneous Coronary Intervention. Interv Cardiol Clin 6: 39-47 [PMID:27886821]

324. Qi AD, Kennedy C, Harden TK and Nicholas RA. (2001) Differential coupling of the human $\mathrm{P} 2 \mathrm{Y}(11)$ receptor to phospholipase $\mathrm{C}$ and adenylyl cyclase. Br J Pharmacol 132: 318-26 [PMID:11156592]

325. Rafehi M, Malik EM, Neumann A, Abdelrahman A, Hanck T, Namasivayam V, Müller CE and Baqi Y. (2017) Development of Potent and Selective Antagonists for the UTP-Activated P2Y 4 Receptor. J Med Chem 60: 3020-3038 [PMID:28306255]

326. Ralevic V and Burnstock G. (1998) Receptors for purines and pyrimidines. Pharmacol Rev 50: 413-492 [PMID:9755289]

327. Ratchford AM, Baker OJ, Camden JM, Rikka S, Petris MJ, Seye CI, Erb L and Weisman GA. (2010) P2Y2 nucleotide receptors mediate metalloprotease-dependent phosphorylation of epidermal growth factor receptor and ErbB3 in human salivary gland cells. J Biol Chem 285: 7545-55 [PMID:20064929]

328. Rieg T, Bundey RA, Chen Y, Deschenes G, Junger W, Insel PA and Vallon V. (2007) Mice lacking $\mathrm{P} 2 \mathrm{Y} 2$ receptors have salt-resistant hypertension and facilitated renal $\mathrm{Na}+$ and water reabsorption. FASEB J 21: 3717-26 [PMID:17575258]

329. Riegel AK, Faigle M, Zug S, Rosenberger P, Robaye B, Boeynaems JM, Idzko M and Eltzschig HK. (2011) Selective induction of endothelial P2Y6 nucleotide receptor promotes vascular inflammation. Blood 117: 2548-55 [PMID:21173118]

330. Roach TI, Rebres RA, Fraser ID, Decamp DL, Lin KM, Sternweis PC, Simon MI and Seaman WE. (2008) Signaling and cross-talk by C5a and UDP in macrophages selectively use PLCbeta3 to regulate intracellular free calcium. $J$ Biol Chem 283: 17351-61 [PMID:18411281]

331. Robaye B, Ghanem E, Wilkin F, Fokan D, Van Driessche W, Schurmans S, Boeynaems JM and Beauwens R. (2003) Loss of nucleotide regulation of epithelial chloride transport in the jejunum of P2Y4-null mice. Mol Pharmacol 63: 777-83 [PMID:12644577]

332. Robichaud J, Fournier JF, Gagné S, Gauthier JY, Hamel M, Han Y, Hénault M, Kargman S, Levesque JF and Mamane Y et al.. (2011) Applying the pro-drug approach to afford highly bioavailable antagonists of P2Y(14). Bioorg Med Chem Lett 21: 4366-8 [PMID:21689930]

333. Rodrigues RJ, Almeida T, Richardson PJ, Oliveira CR and Cunha RA. (2005) Dual presynaptic control by ATP of glutamate release via facilitatory P2X1, P2X2/3, and P2X3 and inhibitory P2Y1, P2Y2, and/or P2Y4 receptors in the rat hippocampus. J Neurosci 25: 6286-95 [PMID:16000618]

334. Ruan HZ and Burnstock G. (2003) Localisation of P2Y1 and P2Y4 receptors in dorsal root, nodose and trigeminal ganglia of the rat. Histochem Cell Biol 120: 415-26 [PMID:14564529]

335. Ruel R, L'heureux A, Thibeault C, Daris JP, Martel A, Price LA, Wu Q, Hua J, Wexler RR and Rehfuss R et al.. (2013) New azole antagonists with high affinity for the P2Y1 receptor. Bioorg Med Chem Lett 23: 3519-22 [PMID:23668989]

336. Sabala P, Czajkowski R, Przybyłek K, Kalita K, Kaczmarek L and Barańska J. (2001) Two subtypes of G protein-coupled nucleotide receptors, P2Y(1) and P2Y(2) are involved in calcium signalling in glioma C6 cells. Br J Pharmacol 132: 393-402 [PMID:11159687]

337. Santiago-Pérez LI, Flores RV, Santos-Berríos C, Chorna NE, Krugh B, Garrad RC, Erb L, Weisman GA and González FA. (2001) P2Y(2) nucleotide receptor signaling in human monocytic cells: activation, desensitization and coupling to mitogen-activated protein kinases. J Cell Physiol 187: 196-208 [PMID:11267999] 
338. Sasaki Y, Hoshi M, Akazawa C, Nakamura Y, Tsuzuki H, Inoue K and Kohsaka S. (2003) Selective expression of Gi/o-coupled ATP receptor P2Y12 in microglia in rat brain. Glia 44: 242250 [PMID:14603465]

339. Savi P, Labouret C, Delesque N, Guette F, Lupker J and Herbert JM. (2001) P2y(12), a new platelet ADP receptor, target of clopidogrel. Biochem Biophys Res Commun 283: 379-83 [PMID:11327712]

340. Schachter JB and Harden TK. (1997) An examination of deoxyadenosine 5'(alphathio)triphosphate as a ligand to define $\mathrm{P} 2 \mathrm{Y}$ receptors and its selectivity as a low potency partial agonist of the P2Y1 receptor. Br J Pharmacol 121: 338-44 [PMID:9154346]

341. Schachter JB, Li Q, Boyer JL, Nicholas RA and Harden TK. (1996) Second messenger cascade specificity and pharmacological selectivity of the human P2Y1-purinoceptor. Br J Pharmacol 118: 167-73 [PMID:8733591]

342. Schachter JB, Sromek SM, Nicholas RA and Harden TK. (1997) HEK293 human embryonic kidney cells endogenously express the P2Y1 and P2Y2 receptors. Neuropharmacology 36: 11817 [PMID:9364473]

343. Schafer R, Sedehizade F, Welte T and Reiser G. (2003) ATP- and UTP-activated P2Y receptors differently regulate proliferation of human lung epithelial tumor cells. Am J Physiol Lung Cell Mol Physiol 285: L376-85 [PMID:12691958]

344. Schnurr M, Toy T, Stoitzner P, Cameron P, Shin A, Beecroft T, Davis ID, Cebon J and Maraskovsky E. (2003) ATP gradients inhibit the migratory capacity of specific human dendritic cell types: implications for P2Y11 receptor signaling. Blood 102: 613-20 [PMID:12649135]

345. Schoenwaelder SM, Ono A, Sturgeon S, Chan SM, Mangin P, Maxwell MJ, Turnbull S, Mulchandani M, Anderson K and Kauffenstein G et al.. (2007) Identification of a unique cooperative phosphoinositide 3-kinase signaling mechanism regulating integrin alpha IIb beta 3 adhesive function in platelets. J Biol Chem 282: 28648-58 [PMID:17673465]

346. Schrader AM, Camden JM and Weisman GA. (2005) P2Y2 nucleotide receptor up-regulation in submandibular gland cells from the NOD.B10 mouse model of Sjögren's syndrome. Arch Oral Biol 50: 533-40 [PMID:15848146]

347. Schreiber R and Kunzelmann K. (2005) Purinergic P2Y6 receptors induce Ca2+ and CFTR dependent Cl- secretion in mouse trachea. Cell Physiol Biochem 16: 99-108 [PMID:16121038]

348. Schwarz UR, Geiger J, Walter U and Eigenthaler M. (1999) Flow cytometry analysis of intracellular VASP phosphorylation for the assessment of activating and inhibitory signal transduction pathways in human platelets--definition and detection of ticlopidine/clopidogrel effects. Thromb Haemost 82: 1145-52 [PMID:10494779]

349. Scrivens M and Dickenson JM. (2006) Functional expression of the P2Y14 receptor in human neutrophils. Eur J Pharmacol 543: 166-73 [PMID:16820147]

350. Scrivens M and Dickenson JM. (2005) Functional expression of the P2Y14 receptor in murine Tlymphocytes. Br J Pharmacol 146: 435-44 [PMID:15997228]

351. Sesma JI, Kreda SM, Steinckwich-Besancon N, Dang H, García-Mata R, Harden TK and Lazarowski ER. (2012) The UDP-sugar-sensing P2Y(14) receptor promotes Rho-mediated signaling and chemotaxis in human neutrophils. Am J Physiol, Cell Physiol 303: C490-8 [PMID:22673622]

352. Seye CI, Gadeau AP, Daret D, Dupuch F, Alzieu P, Capron L and Desgranges C. (1997) Overexpression of P2Y2 purinoceptor in intimal lesions of the rat aorta. Arterioscler Thromb Vasc Biol 17: 3602-10 [PMID:9437211]

353. Seye CI, Yu N, González FA, Erb L and Weisman GA. (2004) The P2Y2 nucleotide receptor mediates vascular cell adhesion molecule-1 expression through interaction with VEGF receptor2 (KDR/Flk-1). J Biol Chem 279: 35679-86 [PMID:15175347]

354. Shaver SR, Rideout JL, Pendergast W, Douglass JG, Brown EG, Boyer JL, Patel RI, Redick CC, Jones AC and Picher M et al.. (2005) Structure-activity relationships of dinucleotides: Potent and selective agonists of P2Y receptors. Purinergic Signal 1: 183-91 [PMID:18404503]

355. Shen J and DiCorleto PE. (2008) ADP stimulates human endothelial cell migration via P2Y1 nucleotide receptor-mediated mitogen-activated protein kinase pathways. Circ Res 102: 448-56 [PMID:18174464]

356. Shin A, Toy T, Rothenfusser S, Robson N, Vorac J, Dauer M, Stuplich M, Endres S, Cebon J and Maraskovsky E et al.. (2008) P2Y receptor signaling regulates phenotype and IFN-alpha secretion of human plasmacytoid dendritic cells. Blood 111: 3062-9 [PMID:17993619]

357. Shiraga M, Miyata S, Kato H, Kashiwagi H, Honda S, Kurata Y, Tomiyama Y and Kanakura Y. (2005) Impaired platelet function in a patient with P2Y12 deficiency caused by a mutation in the translation initiation codon. J Thromb Haemost 3: 2315-23 [PMID:16194207]

358. Shrestha SS, Parmar M, Kennedy C and Bushell TJ. (2010) Two-pore potassium ion channels are inhibited by both G(q/11)- and G(i)-coupled P2Y receptors. Mol Cell Neurosci 43: 363-9 [PMID:20097289]

359. Sil P, Hayes CP, Reaves BJ, Breen P, Quinn S, Sokolove J and Rada B. (2017) P2Y6 Receptor Antagonist MRS2578 Inhibits Neutrophil Activation and Aggregated Neutrophil Extracellular 
Trap Formation Induced by Gout-Associated Monosodium Urate Crystals. J Immunol 198: 428442 [PMID:27903742]

360. Simon J, Filippov AK, Göransson S, Wong YH, Frelin C, Michel AD, Brown DA and Barnard EA. (2002) Characterization and channel coupling of the P2Y(12) nucleotide receptor of brain capillary endothelial cells. J Biol Chem 277: 31390-400 [PMID:12080041]

361. Simon J, Vigne P, Eklund KM, Michel AD, Carruthers AM, Humphrey PP, Frelin C and Barnard EA. (2001) Activity of adenosine diphosphates and triphosphates on a P2Y(T) -type receptor in brain capillary endothelial cells. BrJ Pharmacol 132: 173-82 [PMID:11156575]

362. Skelton L, Cooper M, Murphy M and Platt A. (2003) Human immature monocyte-derived dendritic cells express the G protein-coupled receptor GPR105 (KIAA0001, P2Y14) and increase intracellular calcium in response to its agonist, uridine diphosphoglucose. J Immunol 171: 19419 [PMID:12902497]

363. Springthorpe B, Bailey A, Barton P, Birkinshaw TN, Bonnert RV, Brown RC, Chapman D, Dixon J, Guile SD and Humphries RG et al.. (2007) From ATP to AZD6140: the discovery of an orally active reversible P2Y12 receptor antagonist for the prevention of thrombosis. Bioorg Med Chem Lett 17: 6013-8 [PMID:17827008]

364. Srinivasan S, Mir F, Huang JS, Khasawneh F, Lam SC and Le Breton GC. (2009) The P2Y12 antagonists, 2MeSAMP and cangrelor (ARC69931MX) can inhibit human platelet aggregation through a Gi-independent increase in cAMP levels. J Biol Chem: - [PMID:19346255]

365. Suarez-Huerta N, Pouillon V, Boeynaems J and Robaye B. (2001) Molecular cloning and characterization of the mouse P2Y4 nucleotide receptor. Eur J Pharmacol 416: 197-202 [PMID:11290369]

366. Sun JJ, Liu Y and Ye ZR. (2008) Effects of P2Y1 receptor on glial fibrillary acidic protein and glial cell line-derived neurotrophic factor production of astrocytes under ischemic condition and the related signaling pathways. Neurosci Bull 24: 231-43 [PMID:18668152]

367. Sun R, Carlson NG, Hemmert AC and Kishore BK. (2005) P2Y2 receptor-mediated release of prostaglandin E2 by IMCD is altered in hydrated and dehydrated rats: relevance to AVPindependent regulation of IMCD function. Am J Physiol Renal Physiol 289: F585-92 [PMID:15840771]

368. Sun R, Miller RL, Hemmert AC, Zhang P, Shi H, Nelson RD and Kishore BK. (2005) Chronic dDAVP infusion in rats decreases the expression of P2Y2 receptor in inner medulla and P2Y2 receptor-mediated PGE2 release by IMCD. Am J Physiol Renal Physiol 289: F768-76 [PMID:15914777]

369. Taboubi S, Milanini J, Delamarre E, Parat F, Garrouste F, Pommier G, Takasaki J, Hubaud JC, Kovacic H and Lehmann M. (2007) G alpha(q/11)-coupled P2Y2 nucleotide receptor inhibits human keratinocyte spreading and migration. FASEB J 21: 4047-58 [PMID:17609252]

370. Takasaki J, Kamohara M, Saito T, Matsumoto M, Matsumoto S, Ohishi T, Soga T, Matsushime H and Furuichi K. (2001) Molecular cloning of the platelet P2T(AC) ADP receptor: pharmacological comparison with another ADP receptor, the P2Y(1) receptor. Mol Pharmacol 60: 432-439 [PMID:11502873]

371. Thalji RK, Aiyar N, Davenport EA, Erhardt JA, Kallal LA, Morrow DM, Senadhi S, Burns-Kurtis CL and Marino JP. (2010) Benzofuran-substituted urea derivatives as novel P2Y(1) receptor antagonists. Bioorg Med Chem Lett 20: 4104-7 [PMID:20542694]

372. Tokuyama Y, Hara M, Jones EM, Fan Z and Bell GI. (1995) Cloning of rat and mouse P2Y purinoceptors. Biochem Biophys Res Commun 211: 211-218 [PMID:7779087]

373. Tozaki-Saitoh H, Tsuda M, Miyata H, Ueda K, Kohsaka S and Inoue K. (2008) P2Y12 receptors in spinal microglia are required for neuropathic pain after peripheral nerve injury. J Neurosci 28: 4949-56 [PMID:18463248]

374. Tran MD. (2011) P2 receptor stimulation induces amyloid precursor protein production and secretion in rat cortical astrocytes. Neurosci Lett 492: 155-9 [PMID:21300137]

375. Tran MD, Furones-Alonso O, Sanchez-Molano J and Bramlett HM. (2012) Trauma-induced expression of astrocytic thrombospondin-1 is regulated by P2 receptors coupled to protein kinase cascades. Neuroreport 23: 721-6 [PMID:22776902]

376. Ullmann H, Meis S, Hongwiset D, Marzian C, Wiese M, Nickel P, Communi D, Boeynaems JM, Wolf C and Hausmann R et al.. (2005) Synthesis and structure-activity relationships of suraminderived P2Y11 receptor antagonists with nanomolar potency. J Med Chem 48: 7040-8 [PMID:16250663]

377. Uratsuji H, Tada Y, Kawashima T, Kamata M, Hau CS, Asano Y, Sugaya M, Kadono T, Asahina A and Sato S et al.. (2012) P2Y6 receptor signaling pathway mediates inflammatory responses induced by monosodium urate crystals. J Immunol 188: 436-44 [PMID:22102722]

378. Van Nassauw L, Costagliola A, Van Op den Bosch J, Cecio A, Vanderwinden JM, Burnstock G and Timmermans JP. (2006) Region-specific distribution of the P2Y4 receptor in enteric glial cells and interstitial cells of Cajal within the guinea-pig gastrointestinal tract. Auton Neurosci 126127: 299-306 [PMID:16616701]

379. van Rhee AM, Fischer B, Van Galen PJ and Jacobson KA. (1995) Modelling the P2Y purinoceptor 
using rhodopsin as template. Drug Des Discov 13: 133-154 [PMID:8872457]

380. Vaughan KR, Stokes L, Prince LR, Marriott HM, Meis S, Kassack MU, Bingle CD, Sabroe I, Surprenant A and Whyte MK. (2007) Inhibition of neutrophil apoptosis by ATP is mediated by the P2Y11 receptor. J Immunol 179: 8544-53 [PMID:18056402]

381. Vieira RP, Müller T, Grimm M, von Gernler V, Vetter B, Dürk T, Cicko S, Ayata CK, Sorichter S and Robaye B et al.. (2011) Purinergic receptor type 6 contributes to airway inflammation and remodeling in experimental allergic airway inflammation. Am J Respir Crit Care Med 184: 21523 [PMID:21512170]

382. Vit JP, Jasmin L, Bhargava A and Ohara PT. (2006) Satellite glial cells in the trigeminal ganglion as a determinant of orofacial neuropathic pain. Neuron Glia Biol 2: 247-257 [PMID:18568096]

383. von Kügelgen I and Harden TK. (2011) Molecular pharmacology, physiology, and structure of the P2Y receptors. Adv Pharmacol 61: 373-415 [PMID:21586365]

384. von Kügelgen I and Hoffmann K. (2016) Pharmacology and structure of P2Y receptors. Neuropharmacology 104: 50-61 [PMID:26519900]

385. Waldo GL, Corbitt J, Boyer JL, Ravi G, Kim HS, Ji XD, Lacy J, Jacobson KA and Harden TK. (2002) Quantitation of the P2Y(1) receptor with a high affinity radiolabeled antagonist. Mol Pharmacol 62: 1249-57 [PMID:12391289]

386. Waldo GL and Harden TK. (2004) Agonist binding and Gq-stimulating activities of the purified human P2Y1 receptor. Mol Pharmacol 65: 426-36 [PMID:14742685]

387. Wang L, Jacobsen SE, Bengtsson A and Erlinge D. (2004) P2 receptor mRNA expression profiles in human lymphocytes, monocytes and CD34+ stem and progenitor cells. BMC Immunol 5: 16 [PMID:15291969]

388. Wang L, Olivecrona G, Götberg M, Olsson ML, Winzell MS and Erlinge D. (2005) ADP acting on P2Y13 receptors is a negative feedback pathway for ATP release from human red blood cells. Circ Res 96: 189-96 [PMID:15604418]

389. Wang N, Robaye B, Agrawal A, Skerry TM, Boeynaems JM and Gartland A. (2012) Reduced bone turnover in mice lacking the P2Y(13) receptor of ADP. Mol Endocrinol 26: 142-52 [PMID:22108801]

390. Ward MM, Puthussery T and Fletcher EL. (2008) Localization and possible function of P2Y(4) receptors in the rodent retina. Neuroscience 155: 1262-74 [PMID:18625291]

391. Warny M, Aboudola S, Robson SC, Sevigny J, Communi D, Soltoff SP and Kelly CP. (2001) P2Y(6) nucleotide receptor mediates monocyte interleukin-8 production in response to UDP or lipopolysaccharide. J Biol Chem 276: 26051-26056 [PMID:11349132]

392. Webb TE, Henderson D, King BF, Wang S, Simon J, Bateson AN, Burnstock G and Barnard EA. (1996) A novel G protein-coupled P2 purinoceptor (P2Y3) activated preferentially by nucleoside diphosphates. Mol Pharmacol 50: 258-65 [PMID:8700132]

393. Webb TE, Henderson DJ, Roberts JA and Barnard EA. (1998) Molecular cloning and characterization of the rat $\mathrm{P}_{2} \mathrm{Y}_{4}$ receptor. J Neurochem 71: 1348-1357 [PMID:9751165]

394. Webb TE, Kaplan MG and Barnard EA. (1996) Identification of $6 \mathrm{H} 1$ as a P2Y purinoceptor: P2Y5. Biochem Biophys Res Commun 219: 105-10 [PMID:8619790]

395. Webb TE, Simon J, Krishek BJ, Bateson AN, Smart TG, King BF, Burnstock G and Barnard EA. (1993) Cloning and functional expression of a brain G-protein-coupled ATP receptor. FEBS Lett 324: 219-225 [PMID:8508924]

396. Weisman GA, Woods LT, Erb L and Seye CI. (2012) P2Y receptors in the mammalian nervous system: pharmacology, ligands and therapeutic potential. CNS Neurol Disord Drug Targets 11: 722-38 [PMID:22963441]

397. Weyler S, Baqi Y, Hillmann P, Kaulich M, Hunder AM, Müller IA and Müller CE. (2008) Combinatorial synthesis of anilinoanthraquinone derivatives and evaluation as non-nucleotidederived P2Y2 receptor antagonists. Bioorg Med Chem Lett 18: 223-7 [PMID:18006312]

398. White PJ, Webb TE and Boarder MR. (2003) Characterization of a Ca2+ response to both UTP and ATP at human P2Y11 receptors: evidence for agonist-specific signaling. Mol Pharmacol 63: 1356-63 [PMID:12761346]

399. Wihlborg AK, Balogh J, Wang L, Borna C, Dou Y, Joshi BV, Lazarowski E, Jacobson KA, Arner A and Erlinge D. (2006) Positive inotropic effects by uridine triphosphate (UTP) and uridine diphosphate (UDP) via P2Y2 and P2Y6 receptors on cardiomyocytes and release of UTP in man during myocardial infarction. Circ Res 98: 970-6 [PMID:16543499]

400. Wihlborg AK, Wang L, Braun OO, Eyjolfsson A, Gustafsson R, Gudbjartsson T and Erlinge D. (2004) ADP receptor P2Y12 is expressed in vascular smooth muscle cells and stimulates contraction in human blood vessels. Arterioscler Thromb Vasc Biol 24: 1810-5 [PMID:15308557]

401. Wildman SS, Boone M, Peppiatt-Wildman CM, Contreras-Sanz A, King BF, Shirley DG, Deen PM and Unwin RJ. (2009) Nucleotides downregulate aquaporin 2 via activation of apical P2 receptors. J Am Soc Nephrol 20: 1480-90 [PMID:19423692]

402. Wilkin F, Duhant X, Bruyns C, Suarez-Huerta N, Boeynaems JM and Robaye B. (2001) The P2Y11 receptor mediates the ATP-induced maturation of human monocyte-derived dendritic cells. J Immunol 166: 7172-7 [PMID:11390464] 
403. Wirkner K, Schweigel J, Gerevich Z, Franke H, Allgaier C, Barsoumian EL, Draheim H and Illes P. (2004) Adenine nucleotides inhibit recombinant N-type calcium channels via G proteincoupled mechanisms in HEK 293 cells; involvement of the P2Y13 receptor-type. BrJ Pharmacol 141: 141-51 [PMID:14662731]

404. Wong AM, Chow AW, Au SC, Wong CC and Ko WH. (2009) Apical versus basolateral P2Y(6) receptor-mediated $\mathrm{Cl}(-)$ secretion in immortalized bronchial epithelia. Am J Respir Cell Mol Biol 40: 733-45 [PMID:19011163]

405. Wurm A, Erdmann I, Bringmann A, Reichenbach A and Pannicke T. (2009) Expression and function of P2Y receptors on Müller cells of the postnatal rat retina. Glia 57: 1680-90 [PMID:19373936]

406. Xiang B, Zhang G, Ren H, Sunkara M, Morris AJ, Gartner TK, Smyth SS and Li Z. (2012) The P2Y(12) antagonists, 2MeSAMP and cangrelor, inhibit platelet activation through P2Y(12)/G(i)dependent mechanism. PLoS ONE 7: e51037 [PMID:23236426]

407. Xu J, Morinaga H, Oh D, Li P, Chen A, Talukdar S, Mamane Y, Mancini JA, Nawrocki AR and Lazarowski E et al.. (2012) GPR105 ablation prevents inflammation and improves insulin sensitivity in mice with diet-induced obesity. J Immunol 189: 1992-9 [PMID:22778393]

408. Yamamoto S, Ichishima K and Ehara T. (2007) Regulation of extracellular UTP-activated Clcurrent by P2Y-PLC-PKC signaling and ATP hydrolysis in mouse ventricular myocytes. J Physiol Sci 57: 85-94 [PMID:17291397]

409. Yelovitch S, Barr HM, Camden J, Weisman GA, Shai E, Varon D and Fischer B. (2012) Identification of a promising drug candidate for the treatment of type 2 diabetes based on a P2Y(1) receptor agonist. J Med Chem 55: 7623-35 [PMID:22873688]

410. Yerxa BR, Sabater JR, Davis CW, Stutts MJ, Lang-Furr M, Picher M, Jones AC, Cowlen M, Dougherty R and Boyer J et al.. (2002) Pharmacology of INS37217 [P(1)-(uridine 5')-P(4)- (2'deoxycytidine $5^{\prime}$ )tetraphosphate, tetrasodium salt], a next-generation P2Y(2) receptor agonist for the treatment of cystic fibrosis. J Pharmacol Exp Ther 302: 871-80 [PMID:12183642]

411. Yokomizo T, Izumi T, Chang K, Takuwa Y and Shimizu T. (1997) A G-protein-coupled receptor for leukotriene B4 that mediates chemotaxis. Nature 387: 620-4 [PMID:9177352]

412. Yoshioka K, Saitoh O and Nakata H. (2001) Heteromeric association creates a P2Y-like adenosine receptor. Proc Natl Acad Sci USA 98: 7617-22 [PMID:11390975]

413. Yu J, Ciancetta A, Dudas S, Duca S, Lottermoser J and Jacobson KA. (2018) Structure-Guided Modification of Heterocyclic Antagonists of the P2Y 14 Receptor. J Med Chem 61: 4860-4882 [PMID:29767967]

414. Yu N, Erb L, Shivaji R, Weisman GA and Seye CI. (2008) Binding of the P2Y2 nucleotide receptor to filamin A regulates migration of vascular smooth muscle cells. Circ Res 102: 581-8 [PMID:18202316]

415. Zech G, Hessler G, Evers A, Weiss T, Florian P, Just M, Czech J, Czechtizky W, Görlitzer J and Ruf S et al.. (2012) Identification of high-affinity P2Y12 antagonists based on a phenylpyrazole glutamic acid piperazine backbone. J Med Chem 55: 8615-29 [PMID:22984835]

416. Zeng JW, Liu XH, He WJ, Du L, Zhang JH, Wu XG and Ruan HZ. (2008) Inhibition of ATP-induced glutamate release by MRS2179 in cultured dorsal spinal cord astrocytes. Pharmacology 82: 25763 [PMID:18841035]

417. Zhang D, Gao ZG, Zhang K, Kiselev E, Crane S, Wang J, Paoletta S, Yi C, Ma L and Zhang W et al.. (2015) Two disparate ligand-binding sites in the human P2Y1 receptor. Nature 520: 317-21 [PMID:25822790]

418. Zhang FL, Luo L, Gustafson E, Lachowicz J, Smith M, Qiao X, Liu YH, Chen G, Pramanik B and Laz TM et al.. (2001) ADP is the cognate ligand for the orphan G protein-coupled receptor SP1999. J Biol Chem 276: 8608-15 [PMID:11104774]

419. Zhang FL, Luo L, Gustafson E, Palmer K, Qiao X, Fan X, Yang S, Laz TM, Bayne M and Monsma Jr F. (2002) P2Y(13): identification and characterization of a novel Galphai-coupled ADP receptor from human and mouse. J Pharmacol Exp Ther 301: 705-13 [PMID:11961076]

420. Zhang J, Zhang K, Gao ZG, Paoletta S, Zhang D, Han GW, Li T, Ma L, Zhang W and Müller CE et al.. (2014) Agonist-bound structure of the human P2Y12 receptor. Nature 509: 119-22 [PMID:24784220]

421. Zhang K, Zhang J, Gao ZG, Zhang D, Zhu L, Han GW, Moss SM, Paoletta S, Kiselev E and Lu W et al.. (2014) Structure of the human P2Y12 receptor in complex with an antithrombotic drug. Nature 509: 115-8 [PMID:24670650]

422. Zhang Y, Pop IL, Carlson NG and Kishore BK. (2012) Genetic deletion of the P2Y2 receptor offers significant resistance to development of lithium-induced polyuria accompanied by alterations in PGE2 signaling. Am J Physiol Renal Physiol 302: F70-7 [PMID:21975874]

423. Zhang Y, Sands JM, Kohan DE, Nelson RD, Martin CF, Carlson NG, Kamerath CD, Ge Y, Klein JD and Kishore BK. (2008) Potential role of purinergic signaling in urinary concentration in inner medulla: insights from P2Y2 receptor gene knockout mice. Am J Physiol Renal Physiol 295: F1715-24 [PMID:18829742]

424. Zhang Z, Wang Z, Ren H, Yue M, Huang K, Gu H, Liu M, Du B and Qian M. (2011) P2Y(6) 
agonist uridine 5'-diphosphate promotes host defense against bacterial infection via monocyte chemoattractant protein-1-mediated monocytes/macrophages recruitment. J Immunol 186: 5376-87 [PMID:21444765]

425. Ziegler S, Schillinger M, Funk M, Felber K, Exner M, Mlekusch W, Sabeti S, Amighi J, Minar E and Brunner $\mathrm{M}$ et al.. (2005) Association of a functional polymorphism in the clopidogrel target receptor gene, P2Y12, and the risk for ischemic cerebrovascular events in patients with peripheral artery disease. Stroke 36: 1394-9 [PMID:15933261]

426. Zippel N, Limbach CA, Ratajski N, Urban C, Luparello C, Pansky A, Kassack MU and Tobiasch E. (2012) Purinergic receptors influence the differentiation of human mesenchymal stem cells. Stem Cells Dev 21: 884-900 [PMID:21740266]

427. Zylberg J, Ecke D, Fischer B and Reiser G. (2007) Structure and ligand-binding site characteristics of the human P2Y11 nucleotide receptor deduced from computational modelling and mutational analysis. Biochem J 405: 277-86 [PMID:17338680] 